\title{
Stearoyl CoA desaturase is a gatekeeper that protects human beta cells against lipotoxicity and maintains their identity
}

\author{
Masaya Oshima ${ }^{1}$ - Séverine Pechberty ${ }^{1}$ - Lara Bellini ${ }^{2}$ - Sven O. Göpel ${ }^{3} \cdot$ Mélanie Campana $^{2} \cdot$ Claude Rouch $^{2}$. \\ Julien Dairou ${ }^{4}$. Cristina Cosentino ${ }^{5} \cdot$ Federica Fantuzzi $^{5} \cdot$ Sanna Toivonen $^{5} \cdot$ Piero Marchetti $^{6} \cdot$ Christophe Magnan $^{2}$. \\ Miriam Cnop ${ }^{5,7} \cdot$ Hervé Le Stunff ${ }^{2,8} \cdot$ Raphaël Scharfmann $^{1}$
}

Received: 21 May 2019 / Accepted: 14 October 2019 /Published online: 3 December 2019

(C) The Author(s) 2019

\begin{abstract}
Aims/hypothesis During the onset of type 2 diabetes, excessive dietary intake of saturated NEFA and fructose lead to impaired insulin production and secretion by insulin-producing pancreatic beta cells. The majority of data on the deleterious effects of lipids on functional beta cell mass were obtained either in vivo in rodent models or in vitro using rodent islets and beta cell lines. Translating data from rodent to human beta cells remains challenging. Here, we used the human beta cell line EndoC- $\beta \mathrm{H} 1$ and analysed its sensitivity to a lipotoxic and glucolipotoxic (high palmitate with or without high glucose) insult, as a way to model human beta cells in a type 2 diabetes environment.

Methods EndoC- $\beta \mathrm{H} 1$ cells were exposed to palmitate after knockdown of genes related to saturated NEFA metabolism. We analysed whether and how palmitate induces apoptosis, stress and inflammation and modulates beta cell identity.

Results EndoC- $\beta \mathrm{H} 1$ cells were insensitive to the deleterious effects of saturated NEFA (palmitate and stearate) unless stearoyl CoA desaturase (SCD) was silenced. SCD was abundantly expressed in EndoC- $\beta$ H1 cells, as well as in human islets and human induced pluripotent stem cell-derived beta cells. SCD silencing induced markers of inflammation and endoplasmic reticulum stress and also IAPP mRNA. Treatment with the SCD products oleate or palmitoleate reversed inflammation and endoplasmic reticulum stress. Upon SCD knockdown, palmitate induced expression of dedifferentiation markers such as $S O X 9$, MYC and $H E S 1$. Interestingly, SCD knockdown by itself disrupted beta cell identity with a decrease in mature beta cell markers $I N S, M A F A$ and SLC $30 A 8$ and decreased insulin content and glucose-stimulated insulin secretion.

Conclusions/interpretation The present study delineates an important role for SCD in the protection against lipotoxicity and in the maintenance of human beta cell identity.

Data availability Microarray data and all experimental details that support the findings of this study have been deposited in in the GEO database with the GSE130208 accession code.
\end{abstract}

Keywords Dedifferentiation $\cdot$ Human $\cdot$ Lipotoxicity $\cdot$ Pancreatic beta cell $\cdot$ Type 2 diabetes

Electronic supplementary material The online version of this article (https://doi.org/10.1007/s00125-019-05046-x) contains peer-reviewed but unedited supplementary material, which is available to authorised users.

Raphaël Scharfmann

raphael.scharfmann@inserm.fr

1 Université Paris Descartes, Institut Cochin, Inserm U1016, 123 bd du Port-Royal, 75014 Paris, France

2 Unité Biologie Fonctionnelle et Adaptative, CNRS UMR 8251, Paris, France

3 Bioscience Metabolism, Research and Early Development Cardiovascular Renal and Metabolism, BioPharmaceuticals R\&D, AstraZeneca, Gothenburg, Sweden
Université Paris Descartes CNRS UMR 8601, Paris, France

5 ULB Center for Diabetes Research, Université Libre de Bruxelles, Brussels, Belgium

6 University of Pisa, Department of Clinical and Experimental Medicine, Pisa, Italy

7 Division of Endocrinology, ULB Erasmus Hospital, Université Libre de Bruxelles, Brussels, Belgium

8 Université Paris-Sud, CNRS UMR 9197, Institut des Neurosciences Paris-Saclay (Neuro-PSI) - CNRS UMR 9197, Orsay, France 


\section{Research in context}

\section{What is already known about this subject?}

- Rat and mouse beta cells are highly sensitive to palmitate treatment, which induces dysfunction and apoptosis

- Previous data indicate that treatment of a recently engineered functional human beta cell line, EndoC- $\beta \mathrm{H} 1$, with palmitate does not induce lipotoxicity under standard culture conditions

What is the key question?

- What can investigations using the human EndoC- $\beta \mathrm{H} 1$ beta cell line tell us about lipotoxicity?

What are the new findings?

- Upon stearoyl CoA desaturase (SCD) knockdown in EndoC- $\beta \mathrm{H} 1$ cells, palmitate induces the expression of dedifferentiation markers

- SCD knockdown decreases beta cell identity and induces markers of inflammation and endoplasmic reticulum stress

- Oleate and palmitoleate reverse inflammation and endoplasmic reticulum stress in this model

How might this impact on clinical practice in the foreseeable future?

- Characterising the factors that influence SCD expression and activity may help to define new strategies to overcome beta cell dedifferentiation, dysfunction and apoptosis during type 2 diabetes

$\begin{array}{ll}\begin{array}{l}\text { Abbreviations } \\ \beta H 1-S C D\end{array} & \text { SCD knocked-down EndoC- } \beta \text { H1 (cells) } \\ \text { ER } & \text { Endoplasmic reticulum } \\ \text { GSIS } & \text { Glucose-stimulated insulin secretion } \\ \text { HG } & \text { High glucose } \\ \text { IAPP } & \text { Islet amyloid polypeptide } \\ \text { iPSC } & \text { Induced pluripotent stem cell } \\ \text { PARP } & \text { Poly-(ADP-ribose) polymerase } \\ \text { PI } & \text { Propidium iodide } \\ \text { qRT-PCR } & \text { quantitative real-time PCR } \\ \text { SCD } & \text { Stearoyl CoA desaturase } \\ \text { siCTRL } & \text { Control siRNA } \\ \text { SOX9 } & \text { SRY-box transcription factor } 9\end{array}$

\section{Introduction}

Type 2 diabetes develops as a consequence of a combination of insulin resistance of peripheral tissues and progressive decrease of functional pancreatic beta cell mass. This deficit is manifested by inadequate and insufficient insulin secretion in response to increased circulating glucose levels [1, 2]. Insulin resistance often precedes the development of type 2 diabetes, but it is now well established that pancreatic beta cell failure is a sine qua non condition for hyperglycaemia and type 2 diabetes to develop $[1,2]$.

NEFA represent an important source of energy for pancreatic beta cells in the normal state but can induce beta cell dysfunction and death when present in excessive levels during a prolonged period [1-3]. Chronic availability of fatty acids causes cell death and dysfunction in rodent beta cell lines [4, 5], isolated rodent islets and primary beta cells [6, 7], and animal models of diabetes [3, 8]. Several studies pointed out that the degree of NEFA saturation is important since saturated NEFA (e.g. palmitate or stearate) cause marked apoptosis, whereas unsaturated NEFA (e.g. palmitoleate or oleate) are much less cytotoxic and protect against saturated NEFAmediated toxicity [7, 9-11]. The chronic adverse effects of saturated NEFA on beta cell function and viability are potentiated by the presence of hyperglycaemia, a phenomenon that is particularly seen in rodent beta cells and that has been termed 'glucolipotoxicity' [12, 13]. Numerous studies have suggested different mechanisms by which NEFA mediate beta cell dysfunction and death such as endoplasmic reticulum (ER) stress [14], increased intracellular triacylglycerol [15], reactive oxygen species (ROS) [16, 17], inflammation [14] and de novo synthesis of ceramide [15].

So far, the vast majority of data on the role of NEFA in beta cells has been derived from rodent models, either primary islets or rat and mouse beta cell lines [4, 18-20], with a more limited number of investigations performed using primary human islets $[10,14,15,21-26]$. This is mainly due to the limited access to human islet preparations, which not only contain variable numbers of beta cells from one preparation to the other, but are also contaminated with non-endocrine cells such as exocrine tissue [27].

In this study, we sought to investigate lipotoxicity in a recently engineered functional human beta cell line, 
EndoC- $\beta$ H1 [28]. This line represents a precious tool to study human beta cells in pathophysiological conditions [29]. As an example, EndoC- $\beta \mathrm{H} 1$ cells react to cytokine exposure in a similar manner to primary human beta cells [30]. Moreover, this cell line is suitable for drug screening [31].

\section{Methods}

Culture of EndoC- $\beta \mathrm{H} 1$ cells and treatment EndoC- $\beta \mathrm{H} 1$ cells (Univercell Biosolutions, Toulouse, France [mycoplasma negative]) were cultured as described [28]. They were treated with $400 \mu \mathrm{mol} / 1$ of NEFA (palmitate, stearate, oleate and/or palmitoleate), in the presence of $5.6 \mathrm{mmol} / 1$ (low glucose) or $30 \mathrm{mmol} / \mathrm{l}$ glucose (high glucose [HG]), for the indicated periods ( $24 \mathrm{~h}$ to $72 \mathrm{~h}$ ). NEFA was administered to the cells as a conjugate with fatty acid-free BSA. NEFA/BSA complex was prepared as described [12]. The molar ratio of NEFA to BSA was 5:1. The NEFA stock solutions were diluted in DMEM to obtain a $0.4 \mathrm{mmol} / \mathrm{l}$ final concentration at a fixed concentration of $0.5 \%$ BSA (low glucose and HG plus or minus NEFA). Unconjugated BSA was used as control. In some experiments, EndoC- $\beta \mathrm{H} 1$ cells were treated for $24 \mathrm{~h}$ with $500 \mu \mathrm{mol} / \mathrm{l}$ palmitate pre-complexed to NEFA-free BSA (Roche, Neuilly-sur-Seine, France) in medium supplemented with $1 \%$ FBS. EndoC- $\beta \mathrm{H} 1$ cells were treated with $5 \mu \mathrm{mol} / 1$ thapsigargin for $24 \mathrm{~h}$ (Sigma-Aldrich, Saint Quentin Fallavier, France). EndoC- $\beta \mathrm{H} 1$ cells were passaged and transfected using Lipofectamine RNAiMAX (Life Technologies, Saint Aubin, France) $24 \mathrm{~h}$ later as described $[32,33]$. SMARTpool siRNAs for human ELOVL6 (L-008861-01-0005), SCD (L-005061-00-0020), SCD5 (L-008416-00-0005) or SOX9 (M-021507-00-0020), or ONTARGETplus non-targeting control pool siRNA (siCTRL, D-001810-01-20) were used (Dharmacon, GE Healthcare Life Sciences, Velizy-Villacoublay, France) at a final concentration of $80 \mathrm{nmol} / \mathrm{l}$. In some experiments, EndoC- $\beta \mathrm{H} 1$ cells were transfected as described [33] with $30 \mathrm{nmol} / \mathrm{l}$ control siRNA (Qiagen, Antwerp, Belgium) or three different siRNAs targeting $S C D$ (siSCD; electronic supplementary material [ESM] Table 1, ThermoFisher, Merelbeke, Belgium). $S C D$ knocked down EndoC- $\beta \mathrm{H} 1$ cells will be hereafter referred to as $\beta \mathrm{H} 1-\mathrm{SCD}^{\mathrm{KD}}$. CPT1A-targeting siRNA was purchased from ThermoFisher and was also used at a final concentration of $80 \mathrm{nmol} / \mathrm{l}$ (ThermoFisher, AM1670810564). Briefly, siRNA and Lipofectamine RNAiMAX were combined in OptiMEM and applied to the cells. Medium was changed $2.5 \mathrm{~h}$ later for fresh EndoC- $\beta \mathrm{H} 1$ culture medium. Efficiency of gene knockdown was validated by qRT-PCR (quantitative real-time qPCR) and protein level (for stearoyl CoA desaturase [SCD] and SRY-box transcription factor 9 [SOX9]).
Human islet culture Pancreases were obtained with informed written consent and processed with the approval of the local ethics committee of the University of Pisa. Human islets were isolated at the University of Pisa, Italy, using collagenase digestion and density gradient purification from heartbeating organ donors [34]. The organ donors (three men, five women, age $67 \pm 8$ years [mean \pm SD], BMI $27.3 \pm 4.0 \mathrm{~kg} / \mathrm{m}^{2}$, cause of death cerebral haemorrhage in six, stroke in one and post-anoxic encephalopathy in one) did not have a medical history of diabetes. Human islets were cultured in Ham's F-10 medium as described [14]. Beta cell purity, evaluated by insulin immunocytochemistry in dispersed islet cells, was $47 \pm 10 \%$. Information on human islets is available in the Human Islets checklist in the ESM.

Human induced pluripotent stem cell culture and differentiation into beta cells The previously described human induced pluripotent stem cell (iPSC) line HEL115.6 [35] was differentiated into beta cells using a seven-stage protocol that makes use of monolayer culture on Matrigel-coated plates up to pancreatic progenitor stage 4 and then moves the cells to suspension culture until the last stage of beta cell differentiation [35]. Stage 7 aggregates contained $41 \pm 14 \%$ beta cells (assessed by insulin immunocytochemistry).

Assessment of cell death Live/dead cells were counted following Trypan Blue staining. Caspase 3/7 activity assays were performed using the Promega Apo-ONE Homogenous caspase-3/7 Assay kit as described [36] (Promega, Charbonières-les-Bains, France). As another method for apoptosis detection, cells were stained with the Hoechst $33342(5 \mu \mathrm{g} / \mathrm{ml}$, Sigma-Aldrich) and propidium iodide (PI, $5 \mu \mathrm{g} / \mathrm{ml}$, Sigma-Aldrich) and counted by fluorescence microscopy [37]. The xCELLigence system (ACEA Biosciences, San Diego, CA, USA), which is based on the continuous real-time monitoring of cell adhesion, was used for real-time and label-free monitoring of cell viability and growth [38]. Briefly, EndoC- $\beta \mathrm{H} 1$ cells were seeded into 96-well E-plates coated with extracellular matrix and fibronectin $(50,000$ cells/ well), transfected with siRNA, treated with NEFA or BSA $72 \mathrm{~h}$ later and monitored for up to $72 \mathrm{~h}$.

Insulin content and glucose-stimulated insulin secretion Insulin content and glucose-stimulated insulin secretion (GSIS) were measured as described [39].

RNA isolation, reverse transcription, qRT-PCR and transcriptomic analyses qRT-PCR was performed as described [32]. ACTB or PPIA transcript levels were used as housekeeping genes for normalisation. Primer sequences are listed in ESM Table 2. Global transcriptomic analyses were performed using the Affymetrix 2.0ST gene chip as described [32] (Affymetrix-Thermofisher, Courtaboeuf, France). 
Microarray data and all experimental details are available in the Gene Expression Omnibus (GEO) database (accession GSE130208). Heatmap analyses were generated using webbased Morpheus tool (https://software.broadinstitute.org/ morpheus/; access date: 3 January 2019).

Human IAPP promoter analysis The 797 bp upstream sequence of the IAPP gene, which encodes islet amyloid polypeptide (IAPP), was extracted from NCBI Map viewer/Ace view, and scanned for the presence of SOX9 binding motifs using MatInspector (Genomatix software, https://www. genomatix.de/, access date: 3 January 2019; [40]). Results are presented in ESM Table 3.

Measurement of NEFA levels by GC-MS Cellular saturated and unsaturated NEFA levels were determined by GC-MS as described [41]. Briefly, cells were mixed with BF3 (14\%)/ methanol and heated $\left(100^{\circ} \mathrm{C} ; 40 \mathrm{~min}\right)$. Then, NEFA were extracted using heptane/distilled water $(1: 2)$. NEFA present in the supernatant were evaporated and solubilised in heptane. NEFA methyl esters $(1 \mu \mathrm{l})$ were analysed on GC-MS instrument (Shimadzu interfaced with a GC2010 mass selective detector). Heptadecanoic acid was used as internal standard. The mass spectra and retention indices registered in the Fatty Acid Methyl Esters (FAMEs) GC/MS Library were obtained using the Shimadzu GCMS-QP2010 (Shimadzu, Marne-laVallée, France, https://www.shimadzu.fr, GCMSsolution Ver. 2) .

Immunoblotting Western blots were performed as described [32] using the following antibodies diluted in TBS 3\% BSA 0.1\% Tween-20 (Sigma-Aldrich): poly-(ADP-ribose) polymerase (PARP) (1/1000; 5625S; Cell Signaling, Saint-CyrL'École, France), SCD (1/500; M38; Cell Signaling), MafA (1/500; gift from A. Rezania, BetaLogics, Cambridge, MA, USA), SOX9 (1/500; ab5535; Millipore, Molsheim, France), DDIT3 (1/1000; 5554 Cell Signaling), tubulin (1/2000; T9026; Sigma-Aldrich) and actin (1/2000; A5441; SigmaAldrich). Antibodies were validated by knockdown experiments (SCD, SOX9, MAFA) or have passed applicationspecific testing standards (PARP, DDIT3, actin, tubulin). Species-specific HRP-linked secondary antibodies (1/1000; 7074 and 7076; Cell Signaling) were used.

Statistical analyses Graphs were constructed by using PRISM6 software (GraphPad, San Diego, CA, USA). Quantitative data are presented as the mean \pm SD from three independent experiments. Results were analysed by oneway ANOVA with post hoc Tukey testing for multiple conditions or by $t$ test if only two conditions were being tested (two-tailed). Randomisation and blinding were not carried out. A $p$ value less than 0.05 was considered significant.

\section{Results}

EndoC- $\beta \mathrm{H} 1$ cells are resistant to palmitate toxicity We first analysed the effect of palmitate on EndoC- $\beta \mathrm{H} 1$ cell viability. We did not observe lipotoxicity associated with morphological changes or obvious cell death (characterised by floating cells or debris) in EndoC- $\beta \mathrm{H} 1$ cells treated with $0.4 \mathrm{mmol} / \mathrm{l}$ palmitate (C16:0). The concept of glucolipotoxicity, i.e. the deleterious effects of combined elevated glucose and NEFA concentrations, prompted us to study EndoC- $\beta \mathrm{H} 1$ cell viability following both high glucose and NEFA exposure. The efficiency of HG $(30 \mathrm{mmol} / \mathrm{l})$ treatment was validated by TXNIP mRNA upregulation ([39] and data not shown). Remarkably, we did not observe cell toxicity after palmitate incubation at low glucose $(5.6 \mathrm{mmol} / \mathrm{l})$ or HG (Fig. 1a). To strengthen our investigation, we measured caspase $3 / 7$ cleavage as another marker of cells undergoing apoptosis. Accordingly, we did not observe changes in caspase $3 / 7$ cleavage activity upon palmitate exposure (Fig. 1b). We then quantified PARP cleavage, another apoptosis-related measurement. Thapsigargin induced cell apoptosis as determined by increased PARP cleavage, but this was not the case with palmitate (Fig. 1c, d). Finally, to survey the effects of palmitate over a prolonged period of time (up to $72 \mathrm{~h}$ ) in real time, we used the xCELLigence system. Palmitate treatment did not decrease cell proliferation/survival, but, in fact, it increased it in a time-dependent manner (Fig. 1e).

These data indicate that long chain saturated NEFA such as palmitate, with or without $\mathrm{HG}$, do not induce glucolipotoxicity in EndoC- $\beta$ H1 cells.

\section{$S C D$ is involved in EndoC- $\beta \mathrm{H} 1$ protection against lipotoxicity} Real-time monitoring using xCELLigence suggested that palmitate may in fact increase cell proliferation/survival (Fig. 1). Palmitate can either enter the mitochondrial NEFA $\beta$-oxidation pathway, or be elongated and then desaturated to be incorporated into neutral lipids, two pathways known to be protective to cells (Fig. 2a, [13, 14]). We tested whether altering the enzymes involved in palmitate metabolism modifies the effects of NEFA on EndoC- $\beta \mathrm{H} 1$ cells. We performed knockdown using siRNA against: CPT1A, the rate-limiting-step enzyme of NEFA $\beta$ oxidation; ELOVL6, which elongates palmitate into stearate; and $S C D$ and $S C D 5$, which desaturate palmitate or stearate into palmitoleate (C16:1) or oleate (C18:1), respectively. Each siRNA was specific and efficient ( $>50 \%$ downregulation in the mRNA target) (ESM Fig. 1a). siRNA-transfected EndoC- $\beta \mathrm{H} 1$ cells were next treated with palmitate \pm HG. Upon CPTIA and ELOVL6 knockdown, palmitate did not induce caspase $3 / 7$ cleavage (Fig. 2b). But upon $S C D$ knockdown (Fig. 2c,d, ESM Fig. 1a), palmitate treatment increased caspase 3/7 cleavage in EndoC- $\beta \mathrm{H} 1$ cells (Fig. 2b). To rule out off-target effects, we used three other siRNAs targeting different regions of the SCD mRNA (ESM Table 1, ESM Fig. 1b), and these consistently sensitised EndoC- $\beta \mathrm{H} 1$ cells to palmitate-induced apoptosis measured by 
Fig. 1 Palmitate and high glucose do not induce EndoC- $\beta \mathrm{H} 1$ cell death. EndoC- $\beta \mathrm{H} 1$ cells were either treated with BSA (control), $400 \mu \mathrm{mol} / 1$ palmitate (PAL), $30 \mathrm{mmol} / \mathrm{l}$ glucose (HG) or $\mathrm{HG}+$ PAL for 24 h. (a) Cell morphology. Representative images of cellular aspects after $24 \mathrm{~h}$ of treatment (representative images of three independent experiments; scale bars, $250 \mu \mathrm{m}$ ). (b) Apoptosis was measured by caspase $3 / 7$ cleavage activity $(n=$ 5). (c, d) Representative western blot of PARP cleavage (c) and relative quantification of (cleaved PARP/total PARP) over actin (d) $(n=3-5)$. Thapsigargin treatment was used as positive control. (e) Real-time cell survival during a $72 \mathrm{~h}$ period after BSA, PAL, HG, or HG+PAL treatment measured by xCELLigence technology (representative of one experiment in triplicate). Data represent the means \pm SD. $* p<0.05$ relative to control (BSA)
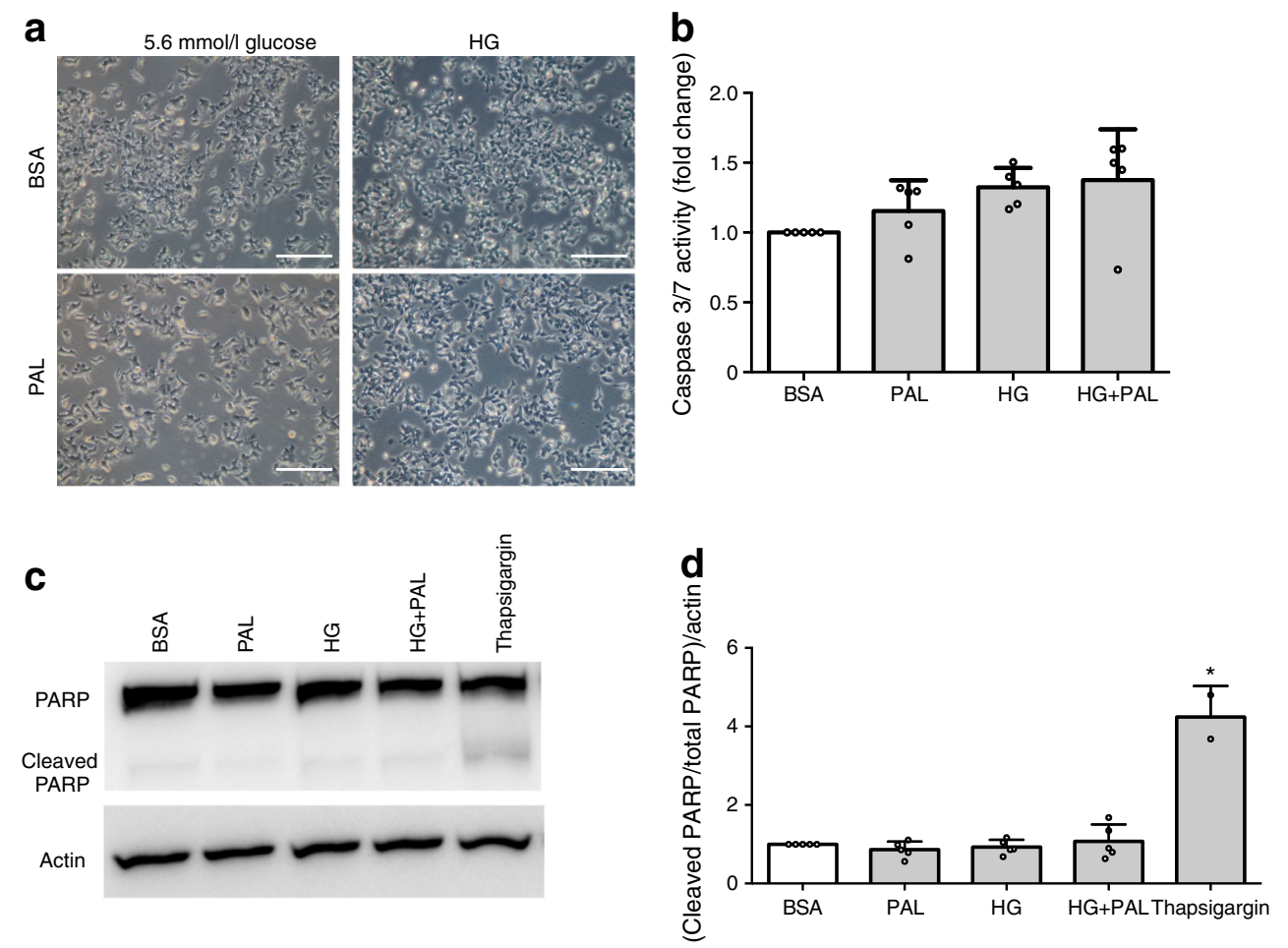

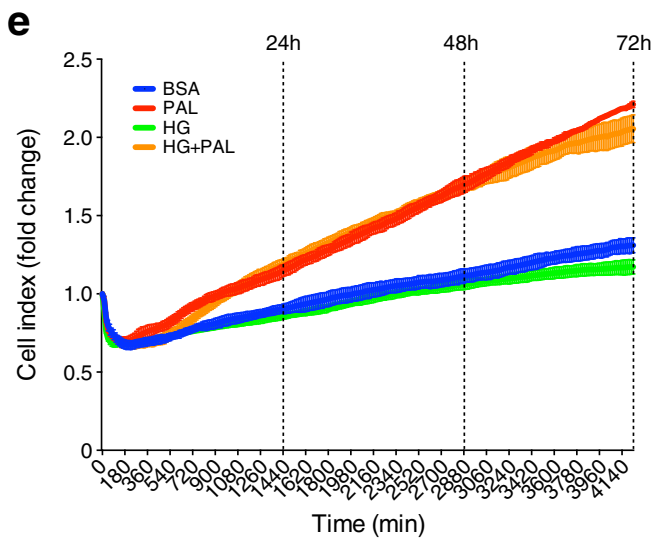

Hoechst 33342 and PI staining (ESM Fig. 1c). Of note, upon SCD5 knockdown, another SCD isoform expressed by human beta cells, palmitate \pm HG did not induce toxicity (Fig. 2b). Moreover, palmitate $\pm \mathrm{HG}$ treatment of $\beta \mathrm{H} 1-\mathrm{SCD}^{\mathrm{KD}}$ cells decreased cell survival as measured by cell morphology, cell counts and xCELLigence (Fig. 2e, g). Similar results were obtained with stearate (C18:0), another long chain saturated NEFA (ESM Fig. 2a, b). Of note, real-time qPCR quantification indicated that, in EndoC- $\beta \mathrm{H} 1$ cells, $S C D$ mRNA expression was high $\left(C_{t} \sim 19\right)$ when compared with other enzymes implicated in saturated NEFA metabolism (CPT1A: $\mathrm{C}_{\mathrm{t}} \sim 26 ;$ ELOVL6: $\mathrm{C}_{\mathrm{t}} \sim 24$; $\left.S C D 5: \mathrm{C}_{\mathrm{t}} \sim 25\right)$. Its expression was also high in human islets and in iPSC-derived beta cells, with an increase in the last stage of human beta cell maturation in this in vitro model of pancreatic endocrine cell development (ESM Fig. 3).
Thus, SCD, an enzyme that catalyses a rate-limiting step in the synthesis of unsaturated NEFA, is involved in EndoC- $\beta \mathrm{H} 1$ cell protection against (gluco)lipotoxicity induced by palmitate and stearate.

Long chain saturated NEFA modulate the expression of stressrelated genes in $\beta \mathrm{H} 1-\mathrm{SCD}{ }^{\mathrm{KD}}$ cells We next analysed in $\beta \mathrm{H} 1$ $\mathrm{SCD}^{\mathrm{KD}}$ cells the effects of palmitate $( \pm \mathrm{HG})$ treatments on the expression of genes previously found to be upregulated by palmitate in human islets, such as genes related to ER stress (ATF3, DDIT3, spliced variant of XBP1) and inflammation $(I L 8, T N F)$ and also IAPP [14]. When EndoC- $\beta \mathrm{H} 1$ cells were transfected with a control siRNA, we did not observe upregulation of the aforementioned genes upon palmitate treatment $( \pm \mathrm{HG})$, confirming the lack of lipotoxicity. However, palmitate treatment of $\beta \mathrm{H} 1-\mathrm{SCD}^{\mathrm{KD}}$ cells induced ATF3, DDIT3, 
Fig. 2 Palmitate and high glucose induce $\beta \mathrm{H} 1-\mathrm{SCD}^{\mathrm{KD}}$ cell death. (a) Schematic representation of enzymes involved in palmitate metabolism. CPT1A, carnitine palmitoyltransferase 1A; MUFA, mono-unsaturated fatty acid; SFA, saturated fatty acid. (b) EndoC- $\beta \mathrm{H} 1$ cells were transfected with siCTRL, $C P T 1 A$ targeting siRNA (siCPT1A), ELOVL6-targeting siRNA (siELOVLO), SCD-targeting siRNA (siSCD) or SCD5targeting siRNA (siSCD5) for $72 \mathrm{~h}$ and then treated with BSA (control), $400 \mu \mathrm{mol} / \mathrm{l}$ palmitate (PAL), $30 \mathrm{mmol} / 1$ glucose (HG) or $\mathrm{HG}+\mathrm{PAL}$ for $24 \mathrm{~h}$. Apoptosis was measured by caspase $3 / 7$ cleavage activity $(n=3)$. (c, d) SCD immunoblotting and quantification following siSCD treatment in EndoC- $\beta \mathrm{H} 1$ cells (representative western blot of three independent experiments). (e-g) EndoC- $\beta \mathrm{H} 1$ cells were transfected with siCTRL or siSCD and treated $72 \mathrm{~h}$ later with BSA, HG, PAL or HG+PAL for 24-72 h. (e) Images represent cellular morphology $24 \mathrm{~h}$ after treatment (representative images of three independent experiments; scale bars, $250 \mu \mathrm{m}$ ). (f) Cell counts after treatment $(n=3)$. (g) Real-time cell survival during a $72 \mathrm{~h}$ period after BSA, HG, PAL or $\mathrm{HG}+\mathrm{PAL}$ treatment measured by xCELLigence technology (representative of two experiments in triplicate). Data represent the means $\pm \mathrm{SD}$. $* p<0.05, * * p<0.01$ and $* * * p<0.001$ relative to control as indicated on the graph

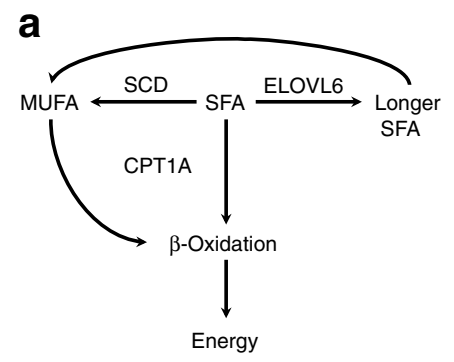

b
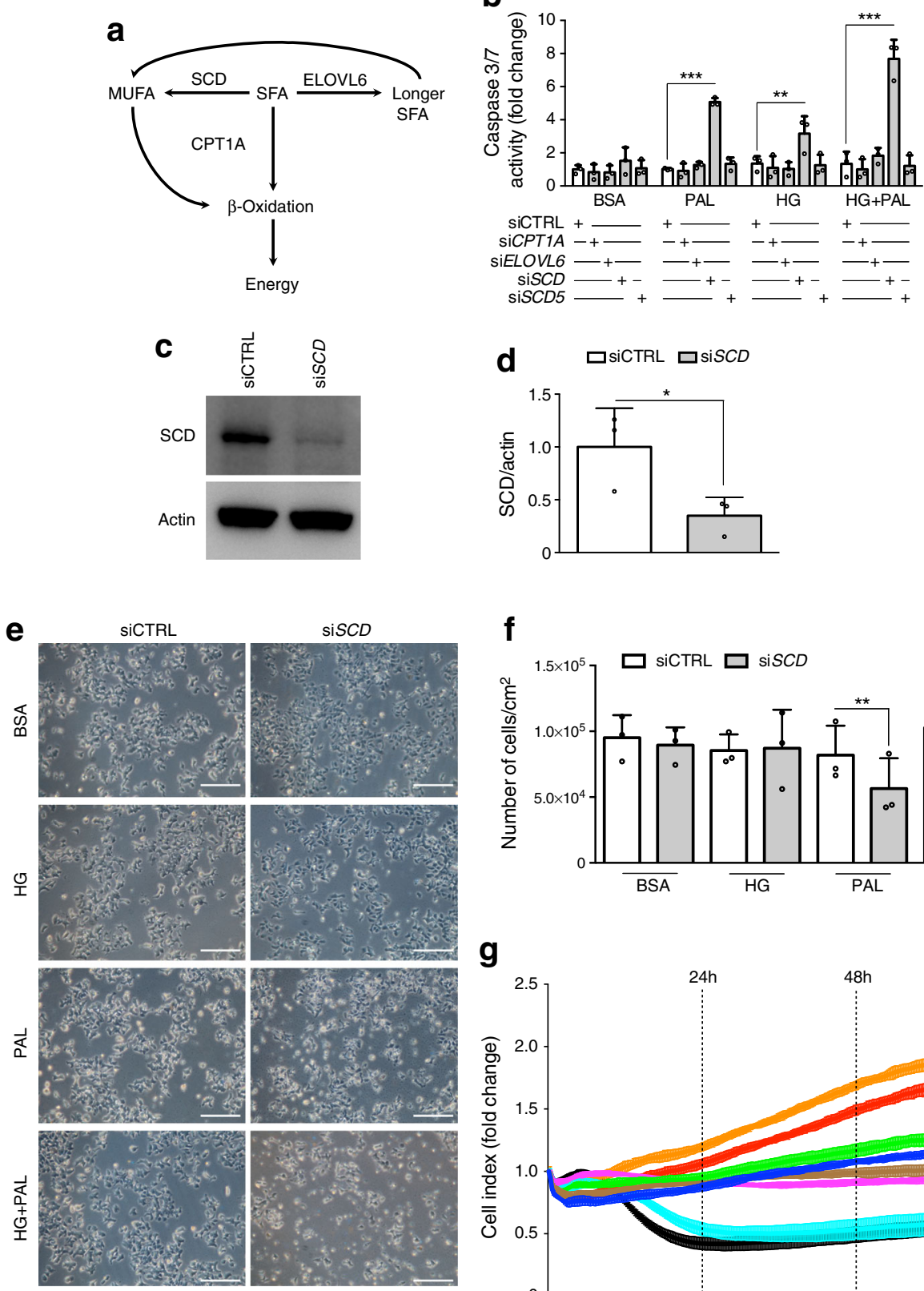

\section{f}

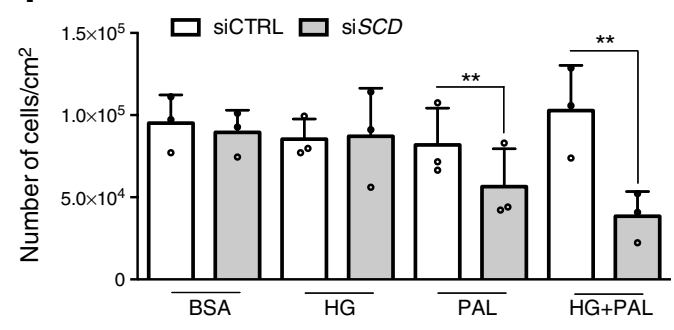

g

d $\square$ SiCTRL $\square \operatorname{SiSCD}$
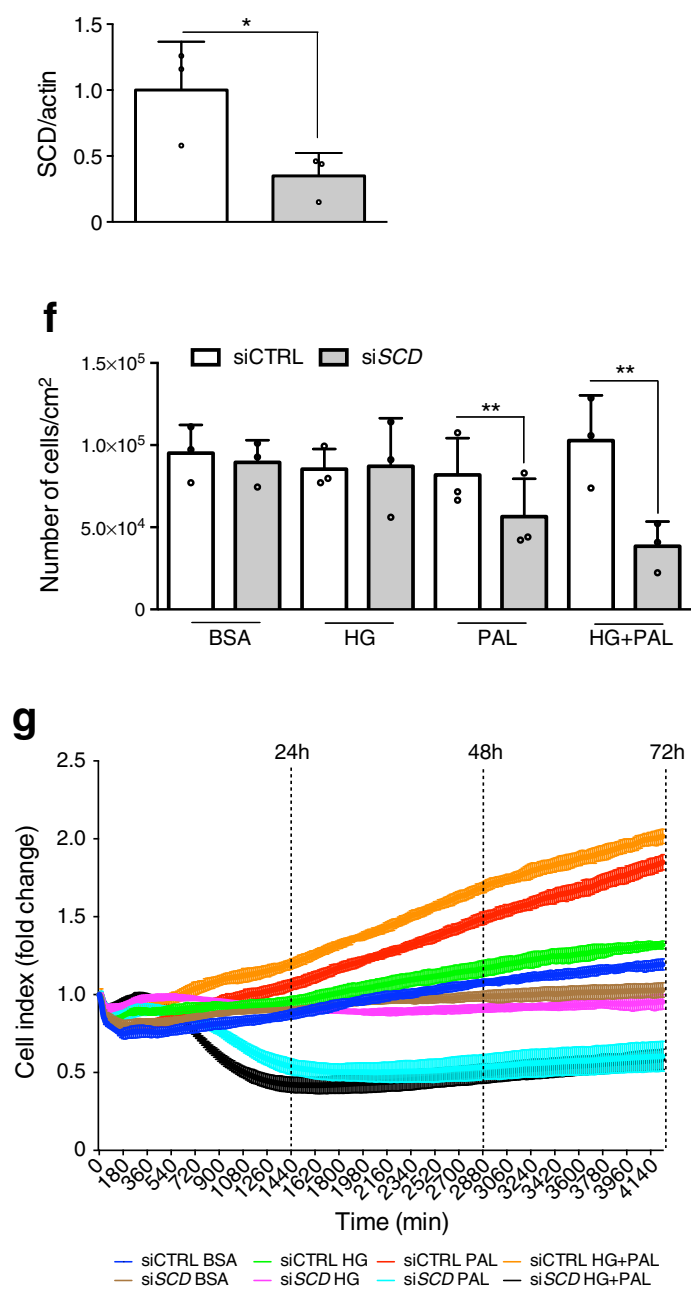

spliced XBP1, IL8, TNF and IAPP mRNAs (Fig. 3a-d, $\mathrm{f}-\mathrm{h}$ ). Similar inductions were observed with stearate (C18:0) treatment (ESM Fig. 4). ER stress marker DDIT3 was also induced at the protein level (Fig. 3e). Of note, ER stress- and inflammation-related gene expression was already induced upon $S C D$ knockdown by itself, suggesting that the inhibition of endogenous NEFA desaturation is sufficient to elicit mild ER and inflammatory stress; exogenous palmitate or stearate treatment further enhanced these inductions (Fig. 3b-d, f-g, ESM Fig. 4) [23].
These data indicate that following $S C D$ knockdown, EndoC- $\beta \mathrm{H} 1$ cells respond to palmitate and stearate in a way similar to that observed in human islets.

Palmitate-induced IAPP upregulation in $\beta \mathrm{H} 1-\mathrm{SCD}^{\mathrm{KD}}$ cells requires SOX9 IAPP is upregulated in several dysfunctional beta cell models. Genomatix analysis suggested eight potent SOX9 binding sites in the human IAPP promoter (Fig. 4a and ESM Table 3). SOX9 is a transcription factor expressed in pancreatic progenitors and in duct cells in the adult pancreas 

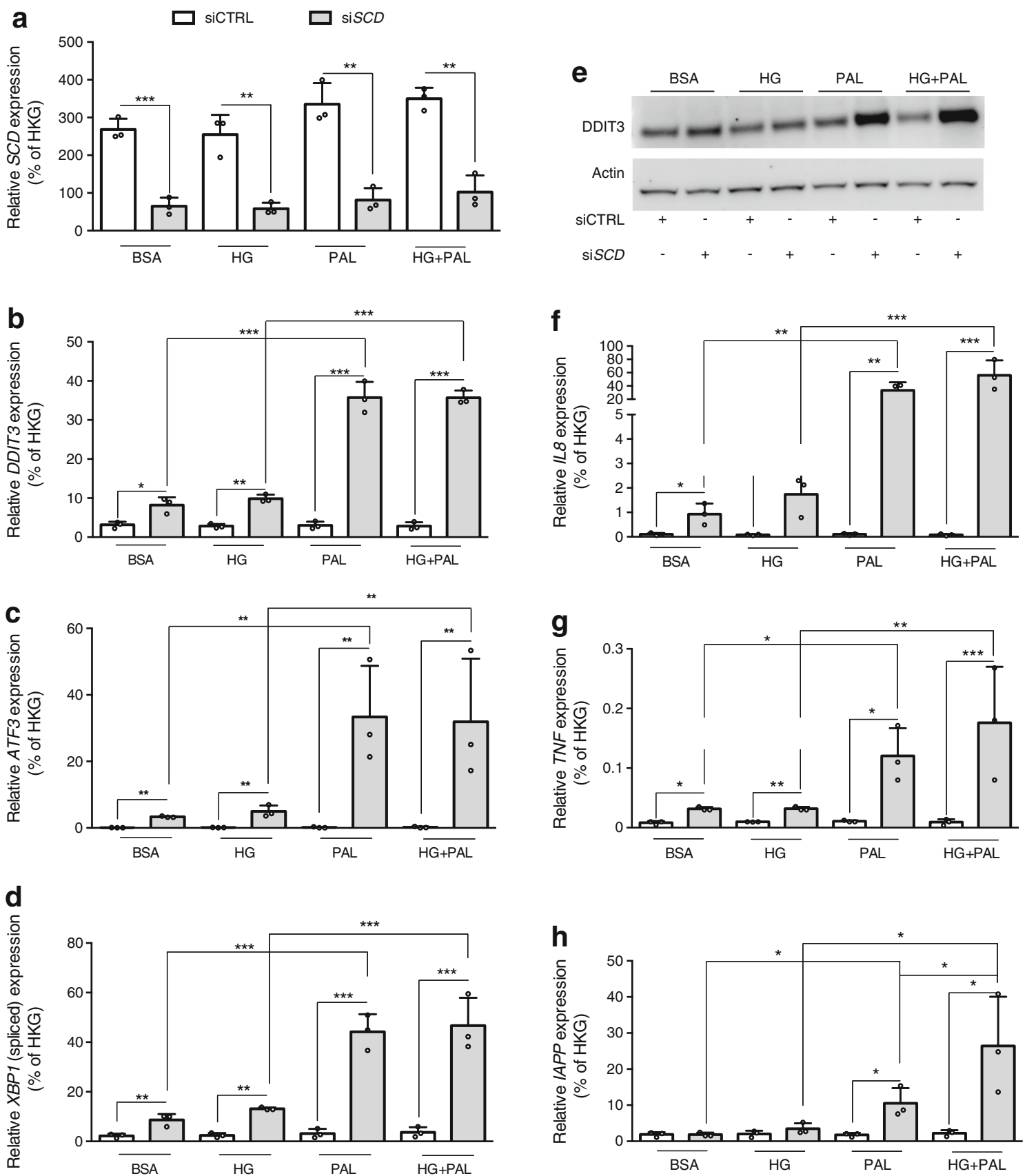

Fig. 3 Palmitate modulates gene expression in $\beta \mathrm{H} 1-\mathrm{SCD}^{\mathrm{KD}}$ cells. EndoC- $\beta \mathrm{H} 1$ cells were transfected with siCTRL or siSCD and treated $72 \mathrm{~h}$ later with BSA (control), $400 \mu \mathrm{mol} / \mathrm{l}$ palmitate (PAL), $30 \mathrm{mmol} / \mathrm{l}$ glucose (HG) or HG+PAL for $24 \mathrm{~h}$. qRT-PCR data show mRNA expression of (a) $S C D$, and (b-d) the ER stress-related genes DDIT3 (b), ATF3 (c) and the spliced variant of $X B P 1$ (d). (e) Western blot of DDIT3 (representative western blot of three independent experiments). (f-h) qRT-PCR

but also in beta cells upon dedifferentiation [32, 42-44]. Here, we observed that SOX9 expression was significantly upregulated in palmitate-treated $\beta \mathrm{H} 1-\mathrm{SCD}^{\mathrm{KD}}$ cells at the mRNA and protein levels (Fig. 4b, c). To study SOX9 involvement in IAPP induction, we prevented SOX9 induction using siRNA in $\beta \mathrm{H} 1-$

data show mRNA expression of the proinflammatory genes $I L 8$ (f), TNF (g) and IAPP (h). mRNA expression is relative to housekeeping genes (HKG). The key in (a) is also applicable to (b-d) and (f-h). Data represent the means $\pm \mathrm{SD}$ of three independent experiments. ${ }^{*} p<0.05$, $* * p<0.01$ and $* * * p<0.001$ relative to control as indicated on the graph

$\mathrm{SCD}^{\mathrm{KD}}$ cells (Fig. 4c-e) and then treated these cells with palmitate + HG. Under this setting, IAPP induction by palmitate $+\mathrm{HG}$ was abolished (Fig. 4f).

Our data thus demonstrate that upregulation of IAPP by palmitate $+\mathrm{HG}$ requires the induction of the beta cell dedifferentiation marker SOX9. 

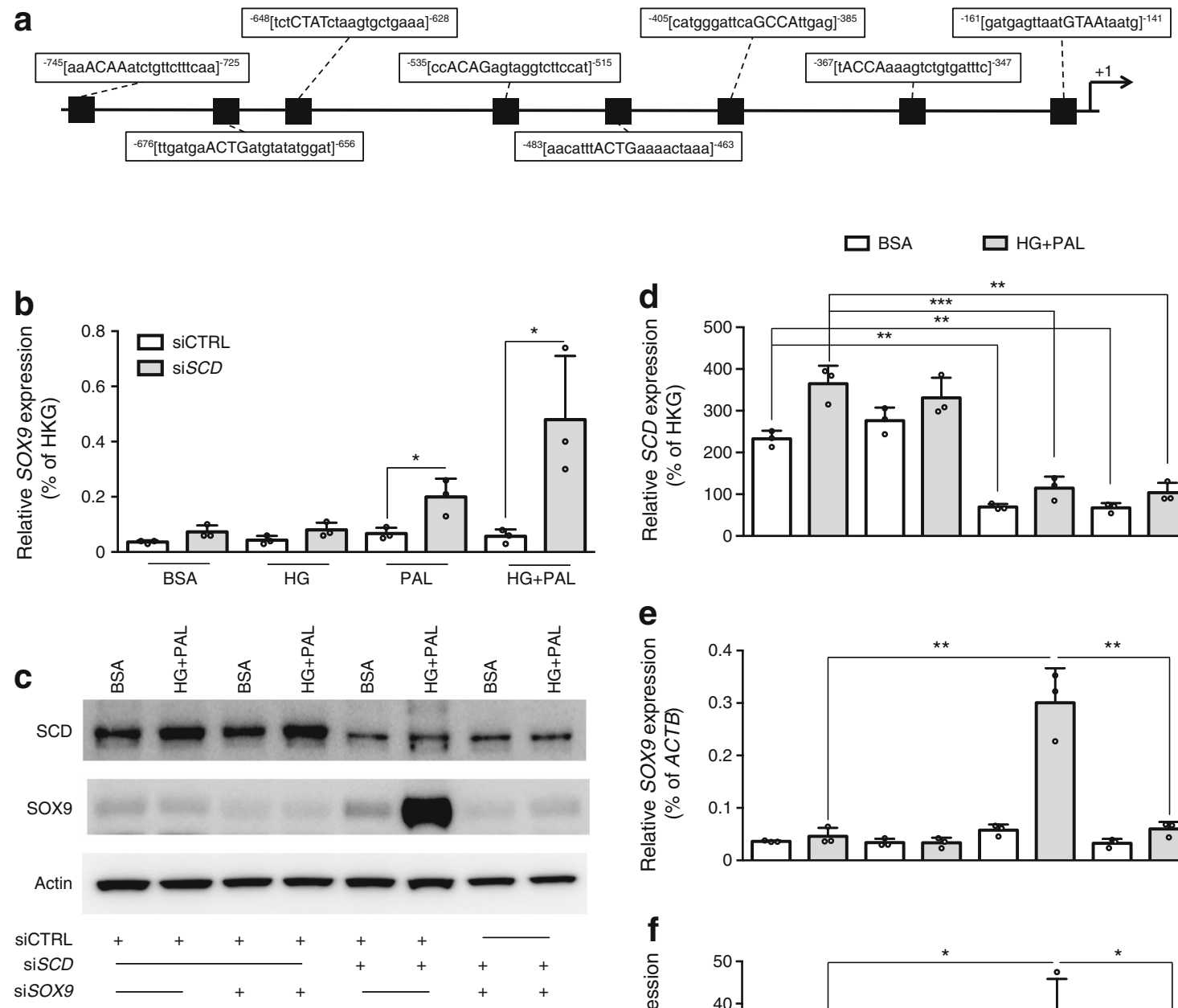

Fig. 4 Palmitate-induced IAPP expression in $\beta \mathrm{H} 1-\mathrm{SCD}^{\mathrm{KD}}$ cells is dependent on SOX9. (a) Schematic representation of the IAPP promoter showing potential SOX9 binding sites identified with MatInspector (Genomatix software). The numbers refer to the nucleotide position upstream of the transcription start site $(+1)$. SOX9 binding motifs are shown in upper case letters. (b) EndoC- $\beta \mathrm{H} 1$ cells were transfected with either siCTRL or siSCD and treated $72 \mathrm{~h}$ later with BSA (control), $400 \mu \mathrm{mol} / \mathrm{l}$ palmitate (PAL), $30 \mathrm{mmol} / \mathrm{l}$ glucose (HG) or HG+PAL for 24 h. qRT-PCR data show $S O X 9$ mRNA expression relative to housekeeping genes (HKG). (c-f) EndoC- $\beta \mathrm{H} 1$ cells were either transfected
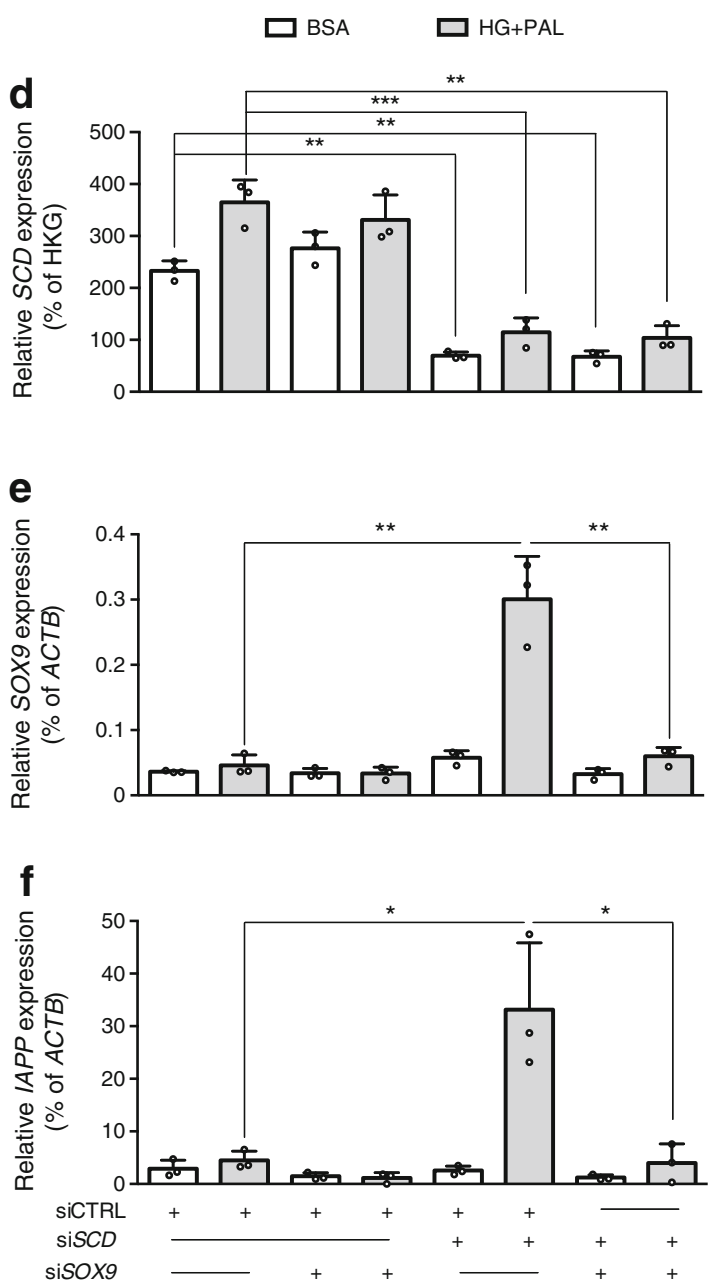

with siCTRL, siSOX9, siSCD or siSCD+siSOX9. Seventy-two hours later, they were treated with BSA or HG+PAL for $24 \mathrm{~h}$. (c) western blot analysis of SCD and SOX9 expression (representative western blot of three independent experiments). (d-f) qRT-PCR data show mRNA expression (relative to $A C T B$ ) of $S C D(\mathbf{d}), S O X 9$ (e) and IAPP (f). The $x$-axis conditions below (f) also apply to $(\mathbf{d}, \mathbf{e})$ and the key above (d) also applies to $(\mathbf{e}, \mathbf{f})$. Data represent the means $\pm \mathrm{SD}$ of three independent experiments. $* p<0.05, * * p<0.01$ and $* * * p<0.001$ relative to control as indicated on the graph

Dedifferentiation is observed upon SCD knockdown We next investigated other described beta cell dedifferentiation markers [32, 42]. We observed HES1 and MYC upregulation in palmitate-treated $\beta \mathrm{H} 1-\mathrm{SCD}^{\mathrm{KD}}$ cells (Fig. $5 \mathrm{a}, \mathrm{b})$. At the same time, the expression of the beta cell-specific markers INS, MAFA and SLC30A8 sharply decreased (Fig. 5c-e). Surprisingly, their expression was

already downregulated in $\beta \mathrm{H} 1-\mathrm{SCD}^{\mathrm{KD}}$ cells alone (without palmitate treatment) (Fig. $5 \mathrm{c}-\mathrm{f}$ ), suggesting that $S C D$ depletion is sufficient to induce EndoC- $\beta \mathrm{H} 1$ cell dedifferentiation. RNA microarray analysis indicated the downregulation of additional beta cell markers such as G6PC2, SLC2A2 and FOXO1 in $\beta \mathrm{H} 1-\mathrm{SCD}^{\mathrm{KD}}$ cells (Fig. $5 \mathrm{~g}$ ), further supporting beta cell dedifferentiation [32, 
42, 45]. We did not observe any upregulation of nonbeta cell endocrine cell markers such as $G C G$ or $S S T$ or exocrine markers such as $H N F 1 B$ and PTF1A (ESM Fig. 5). Finally, insulin content decreased following SCD downregulation (Fig. 5h). Moreover, GSIS was reduced by $38 \%$ in $\beta \mathrm{H} 1-\mathrm{SCD}^{\mathrm{KD}}$ cells (Fig. $5 \mathrm{i}$ ).

Induction of inflammation and ER stress in $\beta \mathrm{H} 1-\mathrm{SCD}{ }^{\mathrm{KD}}$ cells is reduced by oleate and palmitoleate treatment SCD is the rate-limiting enzyme that catalyses the production of palmitoleate/oleate from palmitate/stearate. MS analysis indicated that SCD knockdown in EndoC- $\beta \mathrm{H} 1$ cells decreased basal oleate concentrations with a significant decrease in the oleate/stearate ratio (Table 1). Of note, we did not observe a decrease in basal palmitoleate concentrations after SCD knockdown compared with siCTRL (Table 1), suggesting that SCD is primarily transforming stearate into oleate in EndoC- $\beta \mathrm{H} 1$ cells. Moreover, elongation of $\mathrm{C} 16$ into $\mathrm{C} 18$ NEFA by ELOVL6 might be an important step for long chain fatty acid metabolism in EndoC- $\beta \mathrm{H} 1$ cells. Remarkably, ELOVL6 is slightly upregulated upon SCD knockdown (ESM Fig. 1). However, co-transfection of $S C D$ and ELOVL6 siRNAs did not reverse dedifferentiation, inflammation and ER stress, suggesting that the degree of NEFA saturation is more important than length in conferring toxicity (data not shown).

We next asked whether oleate or palmitoleate supplementation could reverse some phenotypic traits observed in $\beta \mathrm{H} 1-$ $\mathrm{SCD}^{\mathrm{KD}}$ cells. Treatment of $\beta \mathrm{H} 1-\mathrm{SCD}^{\mathrm{KD}}$ cells with oleate and palmitoleate reduced the effects of palmitate/HG on caspase $3 / 7$ cleavage activity that was paralleled by an absence of induction of IL8 and ATF3 (Fig. 6a-c). Finally, in the absence of palmitate/HG, while oleate and palmitatoleate did not reverse the INS, MAFA or SLC30A8 downregulation observed upon SCD knockdown (Fig. 6d-f), the induction of inflammation $(I L 8, T N F)$ and ER stress (spliced XBP1, ATF3) markers was reduced (Fig. $6 \mathrm{~g}-\mathrm{j}$ ).

\section{Discussion}

Chronically elevated saturated NEFA levels can impair the function of pancreatic beta cells. The mechanisms involved in beta cell lipotoxicity induced by saturated NEFA are the subject of active investigations because of its association with the development of type 2 diabetes [2, 3]. However, our knowledge of how saturated NEFA act on human beta cells and induce diabetes is limited. Defining these mechanisms could help to develop new strategies to prevent beta cell dysfunction and death in type 2 diabetes. Rodent models have been useful to better understand the mechanisms of NEFAinduced beta cell dysfunction. However, differences exist between human and rodent beta cells in response to NEFA
[21, 46, 47]. For example, palmitate differentially affects protein acetylation in rodent and human beta cells [47]. Remarkably, human islets appear to be more resistant to apoptosis than rodent RIN1046-38, INS-1 or Min6 cell lines $[21,46,48,49]$. It is thus of major importance to develop human beta cell models of lipotoxicity. As access to primary human islet preparations is limited and variability exists from one human islet preparation to the other [27], we recently developed functional human beta cell lines $[28,50]$ and tested here their use in modelling human beta cell lipotoxicity.

Rat and mouse beta cells are highly sensitive to palmitate treatment that induces dysfunction and apoptosis [3]. On the other hand, previous data indicated that treatment of EndoC- $\beta \mathrm{H} 1$ cells with palmitate does not induce lipotoxicity under standard culture conditions [51, 52]. Our current data further confirm this. By investigating saturated NEFA metabolism and its related enzymes through knockdown using siRNA, we identified SCD as the main brake on palmitate toxicity. SCD is highly expressed in primary human beta cells $([50,51]$ and the present study). Interestingly, elevated SCD levels have been shown to protect against saturated NEFA in a number of cell types, including the mouse beta cell line MIN6 cells and human islets $[21,48,49]$. The working hypothesis is that SCD rapidly desaturates palmitate/stearate into palmitoleate/oleate, and thus decreases their toxicity. Five different SCDs (SCD1-5) have been described in the mouse while there are only two in humans (SCD and SCD5) [53]. It is noteworthy that SCD5 is predominantly expressed in the human brain and pancreatic islets (beta and delta cells), human beta cell lines and pancreatic ductal cells $([53,54]$ and the present study). Even though SCD5 has been shown to desaturate NEFA [55], our data indicate that, while SCD knockdown induces lipotoxicity in EndoC- $\beta \mathrm{H} 1$ cells upon palmitate treatment, this is not the case upon SCD5 knockdown. This suggests that, in human beta cells, SCD plays the dominant role in the desaturation of long chain saturated NEFA. Another possibility is that products of SCD and SCD5 are used for differential lipogenic reactions. Indeed, SCD is known to play a central role in the synthesis of neutral lipids such as triacylglycerol, which are protective for beta cells [11]. In contrast, in neuronal cells overexpressing SCD5, triacylglycerol and phosphatidylethanolamine formation was reduced whereas de novo synthesis of phosphatidylcholine and cholesteryl esters was increased [55]. Additional analyses are needed to unravel SCD5 function in human beta cells. Interestingly, SCD5 is involved in neuronal cell proliferation and differentiation [55] and in survival of MCF-7 cells, in which cancer-associated fibroblasts induced the expression of SCD5 [56].

Our study further shows that palmitate treatment of $\beta \mathrm{H} 1$ $\mathrm{SCD}^{\mathrm{KD}}$ cells induced the expression of genes related to inflammation (IL8,TNF) and ER stress (ATF3, DDIT3, spliced $X B P 1)$. Increased phospholipid saturation upon 

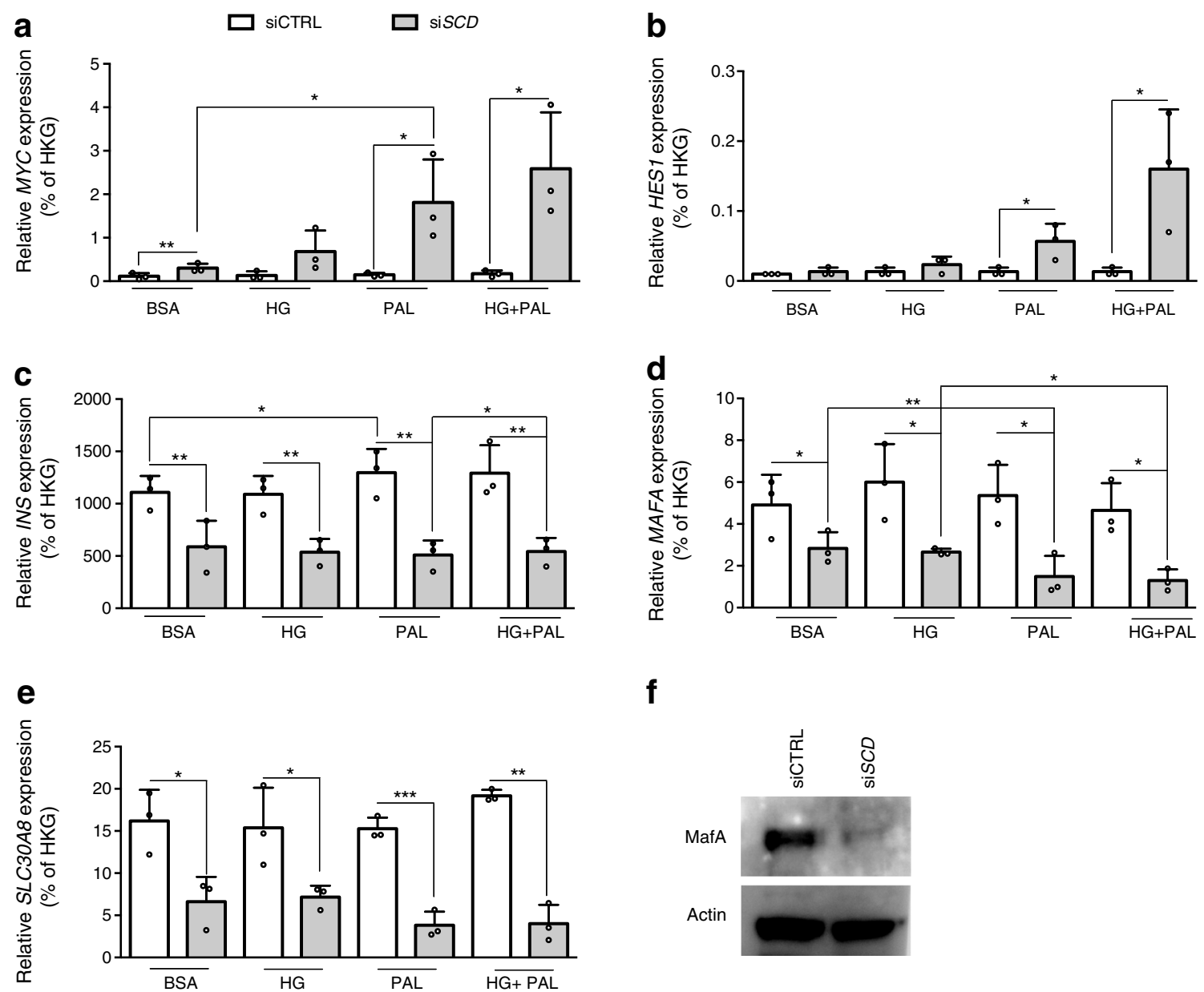

f
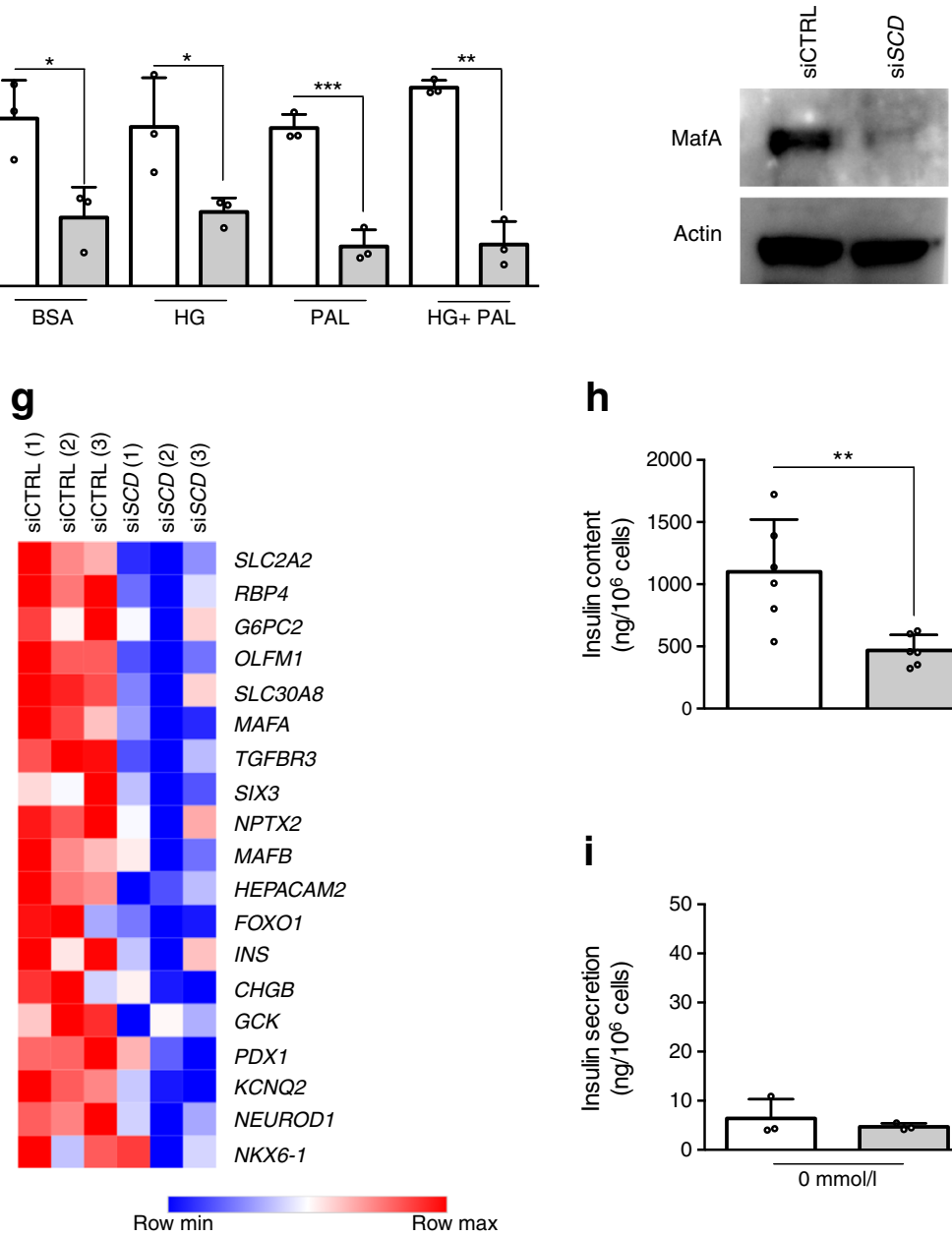

h

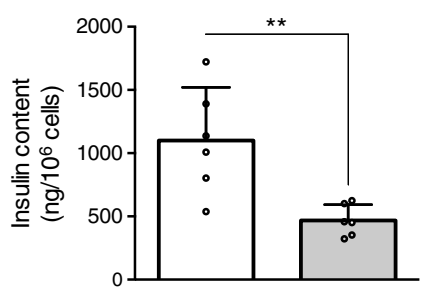

i

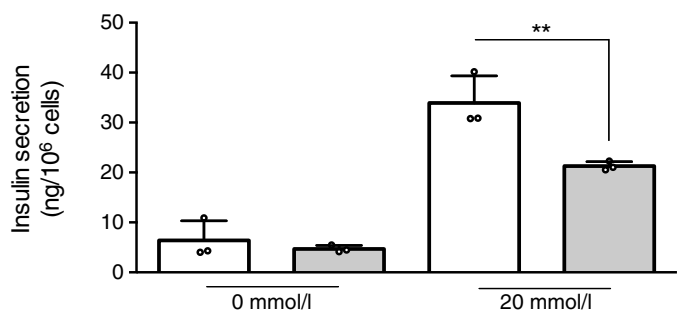

inhibition of SCD could contribute to enhance ER stress in the presence of palmitate, as observed in HeLa cells [57]. These

saturated lipids reduce ER membrane fluidity, which may secondarily lead to $\mathrm{ER} \mathrm{Ca}^{2+}$ depletion, reduced protein 
4 Fig. 5 Palmitate exacerbates dedifferentiation of $\beta \mathrm{H} 1-\mathrm{SCD}^{\mathrm{KD}}$ cells. EndoC- $\beta \mathrm{H} 1$ cells were transfected with siCTRL or siSCD and treated $72 \mathrm{~h}$ later with BSA, $400 \mu \mathrm{mol} / 1$ palmitate (PAL), $30 \mathrm{mmol} / 1$ glucose (HG) or HG+PAL for 24 h. (a-b) qRT-PCR data show mRNA expression of the dedifferentiation markers MYC (a) and HESI (b) $(n=$ 3). (c-e) qRT-PCR data show mRNA expression of the beta cell markers INS (c), MAFA (d) and SLC3OA8 (e) $(n=3)$. (f) Western blot analysis of MafA expression (representative western blot of three independent experiments). (g) Heatmap of beta cell genes upon $S C D$ downregulation (three separate samples for each siRNA). (h, i) Effects of $S C D$ knockdown on GSIS in EndoC- $\beta \mathrm{H} 1$ cells. EndoC- $\beta \mathrm{H} 1$ cells were transfected with siCTRL or siSCD. Insulin content $(\mathbf{h} ; n=6)$ and secretion $(\mathbf{i} ; n=3)$ were assessed 6 days later by stimulation of EndoC$\beta \mathrm{H} 1$ cells with $0 \mathrm{mmol} / \mathrm{l}$ or $20 \mathrm{mmol} / \mathrm{l}$ glucose. The key in (a) also applies to $(\mathbf{b}-\mathbf{e})$ and $(\mathbf{h}, \mathbf{i})$. Data represent the means \pm SD. $* p<0.05, * * p<0.01$ and $* * * p<0.001$ relative to control as indicated on the graph

folding and ER stress [37]. Palmitate also induced the expression of IAPP mRNA levels in $\beta \mathrm{H} 1-\mathrm{SCD}^{\mathrm{KD}}$ cells, as previously observed in human islets treated with palmitate [14]. Remarkably, we found that the expression of SOX9, a beta cell dedifferentiation marker [32, 42, 44], was induced by palmitate in $\beta \mathrm{H} 1-\mathrm{SCD}^{\mathrm{KD}}$ cells, as were HES1 and MYC. SOX 9 activation was necessary for the induction of IAPP by palmitate. Of note, amyloid deposits were recently described surrounding dedifferentiated beta cells in individuals with type 2 diabetes [58]. We propose that beta cell dedifferentiation and induction of SOX9 expression represents an early step that enhances IAPP expression. Human IAPP is coexpressed and co-secreted with insulin. In type 2 diabetes patients, IAPP forms cytotoxic 'amyloid' plaques within islets $[59,60]$. This phenomenon is difficult to study in mice as rodent IAPP does not form amyloid fibres [59, 60]. Palmitate-treated $\beta \mathrm{H} 1-\mathrm{SCD}^{\mathrm{KD}}$ cells may thus represent a new model to understand the regulation of IAPP expression and its potential to form deleterious amyloid fibres [60].

Table 1 Lipid content in whole EndoC- $\beta$ H1 cell lysates following siCTRL or siSCD transfection

\begin{tabular}{lll}
\hline Fatty acids $\left(\mu \mathrm{g} / 10^{6}\right.$ cells $)$ & EndoC $\beta \mathrm{H} 1$-siCTRL & $\beta \mathrm{H} 1-\mathrm{SCD}^{\mathrm{KD}}$ \\
\hline Palmitate & $3.084 \pm 0.156$ & $2.788 \pm 0.110$ \\
Palmitoleate & $2.088 \pm 0.184$ & $2.236 \pm 0.146$ \\
Stearate & $1.351 \pm 0.069$ & $1.522 \pm 0.036$ \\
Oleate & $5.766 \pm 0.209$ & $3.703 \pm 0.006^{* * *}$ \\
Linoleate & $0.411 \pm 0.018$ & $0.331 \pm 0.001^{*}$ \\
$\alpha$-Linolenate & $0.106 \pm 0.041$ & $0.168 \pm 0.022$ \\
Arachidonic acid & $0.095 \pm 0.002$ & $0.189 \pm 0.027^{*}$ \\
Eicosapentaenoic acid & $0.076 \pm 0.053$ & $0.124 \pm 0.008$ \\
Docosapentaenoic & $0.027 \pm 0.002$ & $0.090 \pm 0.044$ \\
Docosahexaenoic acid & $3.682 \pm 0.179$ & $3.500 \pm 0.528$ \\
Palmitoleate/palmitate & $0.675 \pm 0.030$ & $0.801 \pm 0.029$ \\
Oleate/stearate & $4.275 \pm 0.089$ & $2.436 \pm 0.055^{* * *}$ \\
\hline
\end{tabular}

Data are means $\pm \mathrm{SD}$

$* p<0.05$ and $* * * p<0.001$ relative to siCTRL
We observed that SCD knockdown by itself was sufficient to give rise to major phenotypes. It decreased the expression of central beta cell markers such as INS, MAFA and SLC30A8. These observations underline a new role for SCD in maintaining mature beta cell identity. It is noteworthy that SCD is also upregulated during beta cell maturation suggesting an important role in adult beta cell function and identity $([61,62]$ and the present study). SCD knockdown reduced GSIS in EndoC- $\beta \mathrm{H} 1$ cells. Interestingly, it has been shown that extraction of NEFA with NEFA-free BSA from the plasma membrane of MIN6 cells reduced insulin secretion [63]. There, oleate was one of the most extracted NEFA, suggesting that its endogenous synthesis through SCD plays a central role in the regulation of insulin secretion in beta cells. SCD knockdown also induced markers of inflammation and ER stress in EndoC- $\beta \mathrm{H} 1$ cells. The beneficial effects of oleate compared with palmitic acid on insulin resistance and type 2 diabetes is well established [64]. In the present study, SCD knockdown decreased the ratio oleate/palmitate by $30 \%$, suggesting that this reduction could contribute to the deleterious effect of palmitate in $\beta \mathrm{H} 1-\mathrm{SCD}^{\mathrm{KD}}$ cells. In keeping with this, the induction of inflammatory (IL8,TNF) and ER stress (spliced $X B P 1, A T F 3)$ markers was rescued upon addition of oleate and palmitoleate, the products of SCD enzyme reactions. On the other hand, treatment with oleate and palmitoleate did not rescue the expression of beta cell differentiation markers. Future experiments will test whether other conditions of treatment with oleate or palmitoleate (different concentrations, longer exposure time) will reverse the dedifferentiation phenotype observed upon SCD knockdown. Taken together, we propose that SCD is a gatekeeper in human beta cells that protects against dedifferentiation, dysfunction, inflammation and ER stress. $\beta \mathrm{H} 1-\mathrm{SCD}^{\mathrm{KD}}$ cells thus represent an innovative model to discover pathways and molecules that maintain high levels of SCD and protect against such deleterious effects.

Many observations suggest that SCD is important for beta cell adaptation and compensation during type 2 diabetes development in rodents. $S c d 1$ and $S c d 2$ mRNA expression is induced in islets from prediabetic hyperinsulinaemic Zucker Diabetic Fatty rats and their expression decreases when diabetes develops [49]. Consistent with this observation, dietinduced obesity reduces $S c d 1$ mRNA expression in rodent islets [65]. Moreover, while global knockout of $S c d 1$ in mice improves insulin sensitivity, when introduced on the $o b / o b$ background with leptin-deficiency, $S c d 1$ deletion leads to a worsening of diabetes [66]. Importantly, $S C D$ gene expression was lower in beta cell enriched tissue (obtained by laser capture microdissection) from individuals with type 2 diabetes compared with healthy donors [67]. We propose that, over time, in the course of type 2 diabetes progression, SCD expression by beta cells is first induced during compensation in response to insulin resistance, and as the duration of diabetes increases, $\mathrm{SCD}$ expression decreases leading to a decline in 

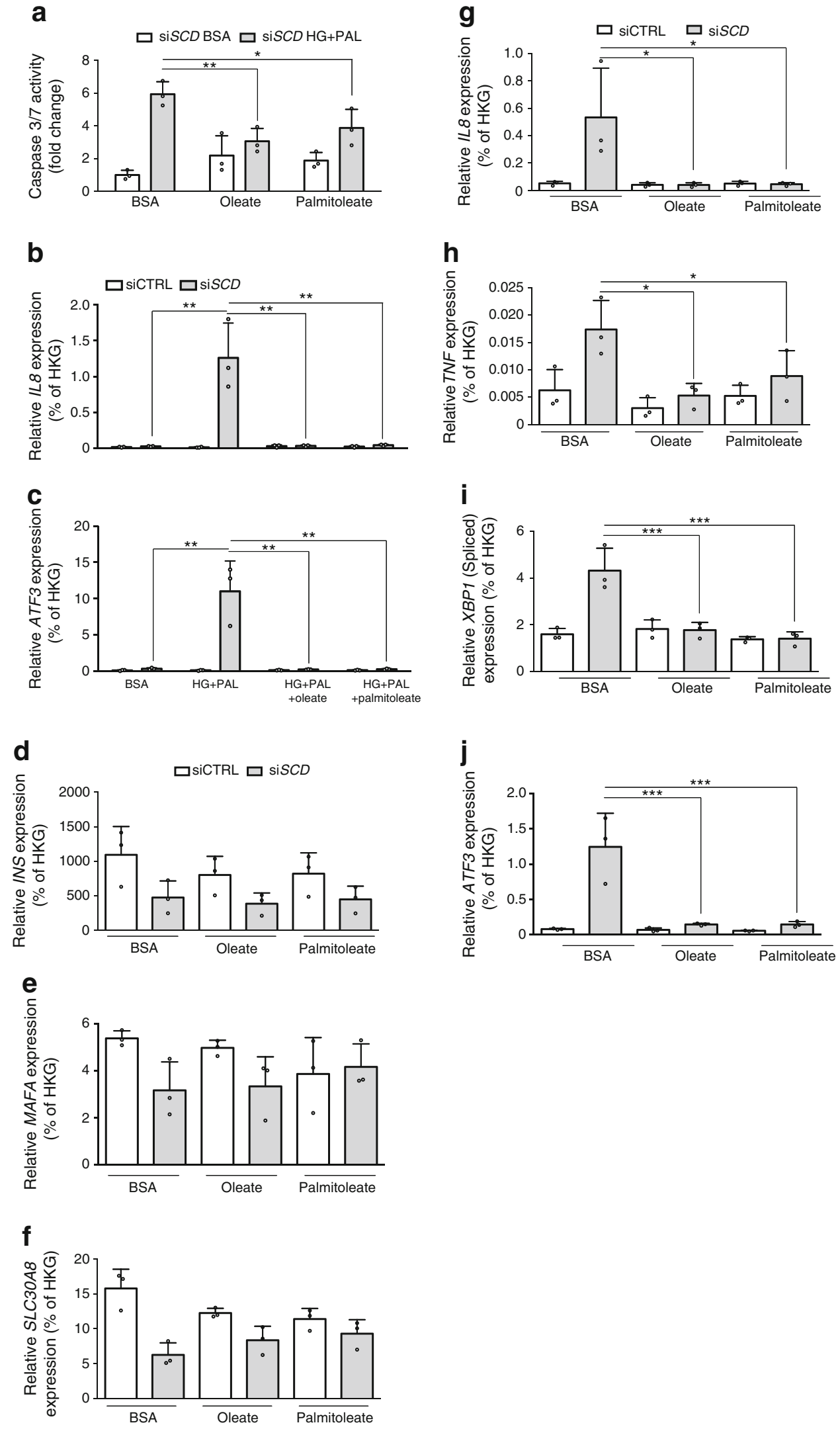

beta cell function. Characterising the factors that influence SCD expression or activity, such as liver X receptor (LXR)/

peroxisome proliferator-activated receptor $\alpha(\operatorname{PPAR} \alpha)$, sterol regulatory element-binding protein 1c (SREBP-1c) and/or 
Fig. 6 Monounsaturated fatty acids reduce gene expression induced in $\beta \mathrm{H} 1-\mathrm{SCD}^{\mathrm{KD}}$ cells. (a) EndoC- $\beta \mathrm{H} 1$ cells were transfected with siSCD for $72 \mathrm{~h}$, then treated with BSA or HG+PAL ( $30 \mathrm{mmol} / \mathrm{l}$ glucose, $400 \mu \mathrm{mol} / \mathrm{l}$ palmitate), and further co-treated with BSA, $400 \mu \mathrm{mol} / 1$ oleate or $400 \mu \mathrm{mol} / \mathrm{l}$ palmitoleate for $24 \mathrm{~h}$. Apoptosis was measured by caspase $3 / 7$ cleavage activity. (b-c) EndoC- $\beta \mathrm{H} 1$ cells were transfected with either siCTRL or siSCD for $72 \mathrm{~h}$, then treated with BSA, HG+PAL, or HG+PAL with either oleate or palmitoleate (both $400 \mu \mathrm{mol} / \mathrm{l}$ ) for $24 \mathrm{~h}$; mRNA levels of IL8 (b) and ATF3 (c) were measured by qRT-PCR. The $x$-axis conditions below (c) also apply to $(\mathbf{b})$. $(\mathbf{d}-\mathbf{j})$ EndoC- $\beta \mathrm{H} 1$ cells were transfected with either siCTRL or siSCD for $72 \mathrm{~h}$, then treated with BSA, $400 \mu \mathrm{mol} / 1$ oleate or $400 \mu \mathrm{mol} / 1$ palmitoleate for $24 \mathrm{~h}$. qRT-PCR data show mRNA expression of the beta cell markers INS (d), MAFA (e) and $S L C 30 A 8$ (f), the inflammatory genes $I L 8(\mathbf{g})$ and $T N F(\mathbf{h})$, and the ER stress genes $X B P 1$ (spliced variant) (i) and ATF3 (j). The keys above (d) and (g) apply to all graphs below them. mRNA expression is relative to housekeeping genes (HKG). Data represent the means $\pm \mathrm{SD}$ of three independent experiments. ${ }^{*} p<0.05, * * p<0.01$ and $* * * p<0.001$ relative to control as indicated on the graph

cholesterol $[68,69]$, will help us define new strategies to overcome beta cell dedifferentiation, dysfunction and death in type 2 diabetes. Our results described above will enable progress on this important topic using $\beta \mathrm{H} 1-\mathrm{SCD}^{\mathrm{KD}}$ as a human beta cell model.

Acknowledgements We would like to thank J. C. Jonas (University of Louvain, Belgium) and W. Le Goff and I. Guillas (both from Sorbonne University, Paris, France) for helpful discussions.

Data availability Microarray data and all experimental details that support the findings of this study have been deposited in in the GEO database with the GSE130208 accession code.

Funding The work leading to this publication has received support from an Aviesan-AstraZeneca programme (SOG and RS), from the Agence Nationale de la Recherche (ANR Betadiamark to CM and RS), from the Innovative Medicines Initiative 2 Joint Undertaking INNODIA under grant agreement No. 115797, supported by the Union's Horizon 2020 research and innovation programme, EFPIA, JDRF and the Leona M. and Harry B. Helmsley Charitable Trust (PM, RS), from the Innovative Medicines Initiative 2 Joint Undertaking RHAPSODY (Risk Assessment and ProgreSsiOn of Diabetes), under grant agreement No. 115881, supported by the European Union's Horizon 2020 research and innovation programme, EFPIA and the Swiss State Secretariat for Education, Research and Innovation (SERI) under contract number 16.0097, resources of which are composed of a financial contribution from the European Union's Seventh Framework Programme (FP7/2007-2013) (PM, CM, MiC, RS) and from the European Union's Horizon 2020 research and innovation programme, project T2DSystems, under grant agreement No 667191 (MiC). The RS laboratory is supported by The Foundation Bettencourt Schueller and belongs to the Laboratoire d'Excellence consortium Revive. The study sponsor was not involved in the design of the study; the collection, analysis, and interpretation of data; writing the report; or the decision to submit the report for publication.

Duality of interest The authors declare that there is no duality of interest associated with this manuscript.

Contribution statement $\mathrm{MO}, \mathrm{SOG}, \mathrm{CM}, \mathrm{MiC}, \mathrm{HLS}$ and RS designed the study. MO, SP, LB, MeC, CR, JD, CC, FF, ST and PM designed and/or performed the experiments. MO, MiC, HLS and RS drafted the manuscript. All authors contributed to the interpretation of data and to the discussion and reviewed/edited the manuscript. RS is the guarantor of this work and, as such, had full access to all of the data in the study and takes responsibility for the integrity of the data and the accuracy of the data analysis. All authors approved the final content of the manuscript.

Open Access This article is distributed under the terms of the Creative Commons Attribution 4.0 International License (http:// creativecommons.org/licenses/by/4.0/), which permits unrestricted use, distribution, and reproduction in any medium, provided you give appropriate credit to the original author(s) and the source, provide a link to the Creative Commons license, and indicate if changes were made.

\section{References}

1. Prentki M, Nolan CJ (2006) Islet beta cell failure in type 2 diabetes. J Clin Invest 116(7):1802-1812. https://doi.org/10.1172/JCI29103

2. Prentki M, Matschinsky FM, Madiraju SRM (2013) Metabolic signaling in fuel-induced insulin secretion. Cell Metab 18(2):162185. https://doi.org/10.1016/j.cmet.2013.05.018

3. Poitout V, Amyot J, Semache M, Zarrouki B, Hagman D, Fontés G (2010) Glucolipotoxicity of the pancreatic beta cell. Biochim Biophys Acta 1801(3):289-298. https://doi.org/10.1016/j.bbalip. 2009.08.006

4. Boslem E, Weir JM, MacIntosh G et al (2013) Alteration of endoplasmic reticulum lipid rafts contributes to lipotoxicity in pancreatic $\beta$-cells. J Biol Chem 288(37):26569-26582. https://doi.org/10. 1074/jbc.M113.489310

5. Kelpe CL, Moore PC, Parazzoli SD, Wicksteed B, Rhodes CJ, Poitout V (2003) Palmitate inhibition of insulin gene expression is mediated at the transcriptional level via ceramide synthesis. J Biol Chem 278(32):30015-30021. https://doi.org/10.1074/jbc. M302548200

6. Maedler K, Spinas GA, Dyntar D, Moritz W, Kaiser N, Donath MY (2001) Distinct effects of saturated and monounsaturated fatty acids on beta-cell turnover and function. Diabetes 50(1):69-76. https:// doi.org/10.2337/diabetes.50.1.69

7. Cnop M, Hannaert JC, Hoorens A, Eizirik DL, Pipeleers DG (2001) Inverse relationship between cytotoxicity of free fatty acids in pancreatic islet cells and cellular triglyceride accumulation. Diabetes 50(8):1771-1777. https://doi.org/10.2337/diabetes.50.8. 1771

8. Biden TJ, Boslem E, Chu KY, Sue N (2014) Lipotoxic endoplasmic reticulum stress, $\beta$ cell failure, and type 2 diabetes mellitus. Trends Endocrinol Metab 25(8):389-398. https://doi.org/10.1016/j.tem. 2014.02.003

9. Sommerweiss D, Gorski T, Richter S, Garten A, Kiess W (2013) Oleate rescues INS-1E $\beta$-cells from palmitate-induced apoptosis by preventing activation of the unfolded protein response. Biochem Biophys Res Commun 441(4):770-776. https://doi.org/10.1016/j. bbrc.2013.10.130

10. El-Assaad W, Buteau J, Peyot M-L et al (2003) Saturated fatty acids synergize with elevated glucose to cause pancreatic beta-cell death. Endocrinology 144(9):4154-4163. https://doi.org/10.1210/en. 2003-0410

11. Listenberger LL, Han X, Lewis SE et al (2003) Triglyceride accumulation protects against fatty acid-induced lipotoxicity. Proc Natl Acad Sci U S A 100(6):3077-3082. https://doi.org/10.1073/pnas. 0630588100

12. Véret J, Coant N, Berdyshev EV et al (2011) Ceramide synthase 4 and de novo production of ceramides with specific $\mathrm{N}$-acyl chain lengths are involved in glucolipotoxicity-induced apoptosis of INS$1 \beta$-cells. Biochem J 438(1):177-189. https://doi.org/10.1042/ BJ20101386 
13. Prentki M, Madiraju SRM (2012) Glycerolipid/free fatty acid cycle and islet $\beta$-cell function in health, obesity and diabetes. Mol Cell Endocrinol 353(1-2):88-100. https://doi.org/10.1016/j.mce.2011. 11.004

14. Cnop M, Abdulkarim B, Bottu G et al (2014) RNA sequencing identifies dysregulation of the human pancreatic islet transcriptome by the saturated fatty acid palmitate. Diabetes 63(6):1978-1993. https://doi.org/10.2337/db13-1383

15. Lupi R, Dotta F, Marselli L et al (2002) Prolonged exposure to free fatty acids has cytostatic and pro-apoptotic effects on human pancreatic islets: evidence that $\beta$-cell death is caspase mediated, partially dependent on ceramide pathway, and Bcl-2 regulated. Diabetes 51(5):1437-1442. https://doi.org/10.2337/diabetes.51.5. 1437

16. Carlsson C, Borg LA, Welsh N (1999) Sodium palmitate induces partial mitochondrial uncoupling and reactive oxygen species in rat pancreatic islets in vitro. Endocrinology 140(8):3422-3428. https:// doi.org/10.1210/endo.140.8.6908

17. Listenberger LL, Ory DS, Schaffer JE (2001) Palmitate-induced apoptosis can occur through a ceramide-independent pathway. J Biol Chem 276(18):14890-14895. https://doi.org/10.1074/jbc. M010286200

18. Wang X, Li H, De Leo D et al (2004) Gene and protein kinase expression profiling of reactive oxygen species-associated lipotoxicity in the pancreatic $\beta$-cell line MIN6. Diabetes 53(1): 129-140. https://doi.org/10.2337/diabetes.53.1.129

19. Janikiewicz J, Hanzelka K, Kozinski K, Kolczynska K, Dobrzyn A (2015) Islet $\beta$-cell failure in type 2 diabetes-within the network of toxic lipids. Biochem Biophys Res Commun 460(3):491-496. https://doi.org/10.1016/j.bbrc.2015.03.153

20. Boslem E, MacIntosh G, Preston AM et al (2011) A lipidomic screen of palmitate-treated MIN6 $\beta$-cells links sphingolipid metabolites with endoplasmic reticulum (ER) stress and impaired protein trafficking. Biochem J 435(1):267-276. https://doi.org/10.1042/ BJ20101867

21. Hall E, Volkov P, Dayeh T et al (2014) Effects of palmitate on genome-wide mRNA expression and DNA methylation patterns in human pancreatic islets. BMC Med 12:103. https://doi.org/10. 1186/1741-7015-12-103

22. Igoillo-Esteve M, Marselli L, Cunha DA et al (2010) Palmitate induces a pro-inflammatory response in human pancreatic islets that mimics CCL2 expression by beta cells in type 2 diabetes. Diabetologia 53(7):1395-1405. https://doi.org/10.1007/s00125010-1707-y

23. Cunha DA, Igoillo-Esteve M, Gurzov EN et al (2012) Death protein 5 and p53-upregulated modulator of apoptosis mediate the endoplasmic reticulum stress-mitochondrial dialog triggering lipotoxic rodent and human $\beta$-cell apoptosis. Diabetes 61(11):2763-2775. https://doi.org/10.2337/db12-0123

24. Lefebvre B, Vandewalle B, Balavoine A-S et al (2012) Regulation and functional effects of ZNT8 in human pancreatic islets. J Endocrinol 214(2):225-232. https://doi.org/10.1530/JOE-12-0071

25. Zhou YP, Grill V (1995) Long term exposure to fatty acids and ketones inhibits $\beta$ cell functions in human pancreatic islets of Langerhans. J Clin Endocrinol Metab 80(5):1584-1590. https:// doi.org/10.1210/jcem.80.5.7745004

26. Jeffrey KD, Alejandro EU, Luciani DS et al (2008) Carboxypeptidase E mediates palmitate-induced $\beta$-cell ER stress and apoptosis. Proc Natl Acad Sci U S A 105(24):8452-8457. https://doi.org/10.1073/pnas. 0711232105

27. Hart NJ, Powers AC (2019) Use of human islets to understand islet biology and diabetes: progress, challenges and suggestions. Diabetologia 62(2):212-222. https://doi.org/10.1007/s00125-0184772-2

28. Ravassard P, Hazhouz Y, Pechberty S et al (2011) A genetically engineered human pancreatic $\beta$ cell line exhibiting glucose- inducible insulin secretion. J Clin Invest 121(9):3589-3597. https://doi.org/10.1172/JCI58447

29. Scharfmann R, Didiesheim M, Richards P et al (2016) Mass production of functional human pancreatic $\beta$-cells: why and how? Diabetes Obes Metab 18(Suppl 1):128-136. https://doi.org/10. 1111/dom. 12728

30. Gurgul-Convey E, Mehmeti I, Plötz T, Jörns A, Lenzen S (2016) Sensitivity profile of the human EndoC- $\beta \mathrm{H} 1$ beta cell line to proinflammatory cytokines. Diabetologia 59(10):2125-2133. https://doi. org/10.1007/s00125-016-4060-y

31. Tsonkova VG, Sand FW, Wolf XA et al (2018) The EndoC- $\beta$ H1 cell line is a valid model of human beta cells and applicable for screenings to identify novel drug target candidates. Mol Metab 8: 144-157. https://doi.org/10.1016/j.molmet.2017.12.007

32. Oshima M, Knoch K-P, Diedisheim M et al (2018) Virus-like infection induces human $\beta$ cell dedifferentiation. JCI Insight 3(3). https://doi.org/10.1172/jci.insight.97732

33. Cnop M, Igoillo-Esteve M, Rai M et al (2012) Central role and mechanisms of $\beta$-cell dysfunction and death in friedreich ataxiaassociated diabetes. Ann Neurol 72(6):971-982. https://doi.org/10. 1002/ana.23698

34. Marchetti P, Bugliani M, Lupi R et al (2007) The endoplasmic reticulum in pancreatic beta cells of type 2 diabetes patients. Diabetologia 50(12):2486-2494. https://doi.org/10.1007/s00125007-0816-8

35. Cosentino C, Toivonen S, Diaz Villamil E et al (2018) Pancreatic $\beta$ cell tRNA hypomethylation and fragmentation link TRMT10A deficiency with diabetes. Nucleic Acids Res 46(19):1030210318. https://doi.org/10.1093/nar/gky839

36. Bellini L, Campana M, Rouch C et al (2018) Protective role of the ELOVL2/docosahexaenoic acid axis in glucolipotoxicity-induced apoptosis in rodent beta cells and human islets. Diabetologia 61(8): 1780-1793. https://doi.org/10.1007/s00125-018-4629-8

37. Cunha DA, Hekerman P, Ladrière L et al (2008) Initiation and execution of lipotoxic ER stress in pancreatic beta-cells. J Cell Sci 121(Pt 14):2308-2318. https://doi.org/10.1242/jcs.026062

38. Culina S, Lalanne AI, Afonso G et al (2018) Islet-reactive CD8+ T cell frequencies in the pancreas, but not in blood, distinguish type 1 diabetic patients from healthy donors. Sci Immunol 3(20): eaao4013. https://doi.org/10.1126/sciimmunol.aao4013

39. Richards P, Rachdi L, Oshima M et al (2018) MondoA is an essential glucose-responsive transcription factor in human pancreatic $\beta$ cells. Diabetes 67(3):461-472. https://doi.org/10.2337/db17-0595

40. Cartharius K, Frech K, Grote K et al (2005) MatInspector and beyond: promoter analysis based on transcription factor binding sites. Bioinformatics 21(13):2933-2942. https://doi.org/10.1093/ bioinformatics/bti473

41. Campana M, Bellini L, Rouch C et al (2018) Inhibition of central de novo ceramide synthesis restores insulin signaling in hypothalamus and enhances $\beta$-cell function of obese Zucker rats. Mol Metab 8: 23-36. https://doi.org/10.1016/j.molmet.2017.10.013

42. Diedisheim M, Oshima M, Albagli O et al (2018) Modeling human pancreatic beta cell dedifferentiation. Mol Metab 10:74-86. https:// doi.org/10.1016/j.molmet.2018.02.002

43. Seymour PA (2014) Sox9: a master regulator of the pancreatic program. Rev Diabet Stud 11(1):51-83. https://doi.org/10.1900/ RDS.2014.11.51

44. Puri S, Akiyama H, Hebrok M (2013) VHL-mediated disruption of Sox9 activity compromises $\beta$-cell identity and results in diabetes mellitus. Genes Dev 27(23):2563-2575. https://doi.org/10.1101/ gad.227785.113

45. Accili D, Talchai SC, Kim-Muller JY et al (2016) When $\beta$-cells fail: lessons from dedifferentiation. Diabetes Obes Metab 18:117-122. https://doi.org/10.1111/dom.12723

46. Eitel K, Staiger H, Rieger J et al (2003) Protein kinase C delta activation and translocation to the nucleus are required for fatty 
acid-induced apoptosis of insulin-secreting cells. Diabetes 52(1): 991-997. https://doi.org/10.1038/s41598-017-13908-w

47. Ciregia F, Bugliani M, Ronci M et al (2017) Palmitate-induced lipotoxicity alters acetylation of multiple proteins in clonal $\beta$ cells and human pancreatic islets. Sci Rep 7(1):1-12. https://doi.org/10. 1038/s41598-017-13908-w

48. Busch AK, Gurisik E, Cordery DV et al (2005) Increased fatty acid desaturation and enhanced expression of stearoyl coenzyme A desaturase protects pancreatic beta-cells from lipoapoptosis. Diabetes 54(10):2917-2924. https://doi.org/10.1016/j.wneu.2016. 10.065

49. Green CD, Olson LK (2011) Modulation of palmitate-induced endoplasmic reticulum stress and apoptosis in pancreatic $\beta$-cells by stearoyl-CoA desaturase and Elovl6. Am J Physiol Endocrinol Metab 300(4):E640-E649. https://doi.org/10.1152/ajpendo.00544. 2010

50. Scharfmann R, Pechberty S (2014) Development of a conditionally immortalized human pancreatic $\beta$ cell line. J Clin Invest 124:1-12. https://doi.org/10.1172/JCI72674.very

51. Krizhanovskii C, Kristinsson H, Elksnis A et al (2017) EndoC- $\beta \mathrm{H} 1$ cells display increased sensitivity to sodium palmitate when cultured in DMEM/F12 medium. Islets 9(3):e1296995. https://doi. org/10.1080/19382014.2017.1296995

52. Fred RG, Boddeti SK, Lundberg M, Welsh N (2015) Imatinib mesylate stimulates low-density lipoprotein receptor-related protein 1-mediated ERK phosphorylation in insulin-producing cells. Clin Sci (Lond) 128(1):17-28. https://doi.org/10.1042/CS20130560

53. Wang J, Yu L, Schmidt RE et al (2005) Characterization of HSCD5, a novel human stearoyl-CoA desaturase unique to primates. Biochem Biophys Res Commun 332(3):735-742. https://doi.org/ 10.1016/j.bbrc.2005.05.013

54. Segerstolpe $\AA$, Palasantza A, Eliasson P et al (2016) Single-cell transcriptome profiling of human pancreatic islets in health and type 2 diabetes. Cell Metab 24(4):593-607. https://doi.org/10.1016/j. cmet.2016.08.020

55. Sinner DI, Kim GJ, Henderson GC, Igal RA (2012) StearoylCoA desaturase-5: a novel regulator of neuronal cell proliferation and differentiation. PLoS One 7(6):e39787. https://doi.org/10.1371/ journal.pone.0039787

56. Angelucci C, D'Alessio A, Iacopino F et al (2018) Pivotal role of human stearoyl-CoA desaturases (SCD1 and 5) in breast cancer progression: oleic acid-based effect of SCD1 on cell migration and a novel pro-cell survival role for SCD5. Oncotarget 9(36): 24364-24380. https://doi.org/10.18632/oncotarget.25273

57. Ariyama H, Kono N, Matsuda S, Inoue T, Arai H (2010) Decrease in membrane phospholipid unsaturation induces unfolded protein response. J Biol Chem 285(29):22027-22035. https://doi.org/10. 1074/jbc.M110.126870

58. Spijker HS, Song H, Ellenbroek JH et al (2015) Loss of $\beta$-cell identity occurs in type 2 diabetes and is associated with islet amyloid deposits. Diabetes 64(8):2928-2938. https://doi.org/10. 2337/db14-1752

59. Abedini A, Schmidt AM (2013) Mechanisms of islet amyloidosis toxicity in type 2 diabetes. FEBS Lett 587(8):1119-1127. https:// doi.org/10.1016/j.febslet.2013.01.017

60. Westermark P, Andersson A, Westermark GT (2011) Islet amyloid polypeptide, islet amyloid, and diabetes mellitus. Physiol Rev 91(3):795-826. https://doi.org/10.1152/physrev.00042.2009

61. Blodgett DM, Nowosielska A, Afik S et al (2015) Novel observations from next-generation RNA sequencing of highly purified human adult and fetal islet cell subsets. Diabetes 64(9):31723181. https://doi.org/10.2337/db15-0039

62. Hrvatin S, O'Donnell CW, Deng F et al (2014) Differentiated human stem cells resemble fetal, not adult, $\beta$ cells. Proc Natl Acad Sci U S A 111(8):3038-3043. https://doi.org/10.1073/pnas. 1400709111

63. Hauke S, Keutler K, Phapale P, Yushchenko DA, Schultz C (2018) Endogenous fatty acids are essential signaling factors of pancreatic $\beta$-cells and insulin secretion. Diabetes 67(10):1986-1998. https:// doi.org/10.2337/db17-1215

64. Palomer X, Pizarro-Delgado J, Barroso E, Vázquez-Carrera M (2018) Palmitic and oleic acid: the yin and yang of fatty acids in type 2 diabetes mellitus. Trends Endocrinol Metab 29(3):178-190. https://doi.org/10.1016/j.tem.2017.11.009

65. Tang N, Matsuzaka T, Suzuki M et al (2014) Ablation of Elovl6 protects pancreatic islets from high-fat diet-induced impairment of insulin secretion. Biochem Biophys Res Commun 450(1):318-323. https://doi.org/10.1016/j.bbrc.2014.05.113

66. Flowers JB, Rabaglia ME, Schueler KL et al (2007) Loss of stearoyl-CoA desaturase-1 improves insulin sensitivity in lean mice but worsens diabetes in leptin-deficient obese mice. Diabetes 56(5): 1228-1239. https://doi.org/10.2337/db06-1142

67. Marselli L, Thorne J, Dahiya S et al (2010) Gene expression profiles of beta-cell enriched tissue obtained by laser capture microdissection from subjects with type 2 diabetes. PLoS One 5(7): e11499. https://doi.org/10.1371/journal.pone.0011499

68. Hellemans KH, Hannaert J-C, Denys B et al (2009) Susceptibility of pancreatic beta cells to fatty acids is regulated by LXR/PPAR $\alpha$ dependent stearoyl-coenzyme A desaturase. PLoS One 4(9):e7266. https://doi.org/10.1371/journal.pone.0007266

69. Kim H-J, Miyazaki M, Ntambi JM (2002) Dietary cholesterol opposes PUFA-mediated repression of the stearoyl-CoA desaturase-1 gene by SREBP-1 independent mechanism. J Lipid Res 43(10):1750-1757. https://doi.org/10.1194/jlr.m100433-jlr200

Publisher's note Springer Nature remains neutral with regard to jurisdictional claims in published maps and institutional affiliations. 